\title{
Sociologie Românească
}

ISSN: 2668-1455 (print), ISSN: 1220-5389 (electronic)

\section{POLITICI SOCIALE ADRESATE FENOMENULUI ÎMBĂTRÂNIRII POPULAȚIEI}

Mariana STANCIU

Sociologie Românească, 2020, vol. 18, Issue 1, pp. 115-145

https://doi.org/10.33788/sr.18.1.5

Published by:

Expert Projects Publishing House

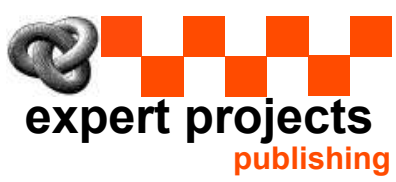

On behalf of: Asociația Română de Sociologie 


\title{
POLITICI SOCIALE ADRESATE FENOMENULUI ÎMBĂTRÂNIRII POPULAT, IEI
}

\author{
Mariana STANCIU ${ }^{1}$
}

\begin{abstract}
The phenomenon of global demographic aging has been going on for several years. The present article presents the basic tendency of this phenomenon, with express reference to the specificity of the phenomenon in Romania and inserts the following topics: the trends of global and European demographic aging, the international institutions and documents focused on domain management, the demographic forecast and European social policies, the characteristics of the aging trend in Romania, the living conditions of the elderly in Romania, the social policies and the forecast of the budgetary expenditures allocated until 2070 in Romania, and finally conclusions. The article is based on information and data published by the UN, the World Health Organization, the OECD, the Council of Europe, EUROSTAT, documents of the National Institute of Statistics from Romania and so on.
\end{abstract}

Keywords: trend; forecast; assistance; expenses; services.

\section{Introducere}

Fenomenul îmbătrânirii demografice se manifestă deja, de câteva decenii, în multe state ale lumii. Reducerea natalităţii şi creșterea numărului de vârstnici schimbă continuu echilibrul dintre generaţii în toate țările lumii, inclusiv în România. Această tendinţă se va menţine şi în prima jumătate a secolului al XXIlea. Dacă în anul 1950 ponderea vârstnicilor era de 8\% (Divizia pentru Populaţie a Departamentului Afacerilor Socio-Economice din cadrul Naţiunilor Unite, 2010), în anul 2050 ponderea vârstnicilor va depăşi $22 \%$ din populaţia mondială. Etapa actuală a fenomenului este ireversibilă pe termen mediu. Ca urmare, instituții de profil ale ONU au emis rezoluții încă din anii '80, și au implementat politici de gestionare a acestui fenomen. Prima Conferință Mondială pe tema Îmbătrânirii

${ }^{1}$ Institutul de Cercetare a Calității Vieții, Institutul Național de Cercetări Economice „Costin C. Kirițescu”, Academia Română, Calea 13 Septembrie nr. 13, Sector 5, 050711, București, România. E-mail: mariana3stanciu@gmail.com. 
Demografice a avut loc în anul 1981, cu acest prilej ONU lansând „Vienna International Plan of Action on Ageing" (Planul de Acțiune în domeniul Îmbătrânirii de la Viena). În anul 1991 Adunarea Generală a ONU a adoptat United Nations Principles for Older Persons (Principiile ONU pentru Persoanele Vârstnice), cuprinzând 18 paragrafe privind independența, participarea, asistarea și îngrijirea, dreptul la autorealizare și demnitate ale persoanelor vârstnice. La Conferinţa din anul 1999, Adunarea Generală a ONU a declarat anul 1999 An Internațional al Persoanelor Vârstnice, iar ziua de 1 Octombrie - Ziua Internațională a Persoanelor Vârstnice. În anul 2002, la Second World Assembly on Ageing de la Madrid au fost proclamate principiile politicilor internaționale pentru secolul 21 în cadrul Political Declaration and the Madrid International Plan of Action on Ageing. Problematica îmbătrânirii demografice a fost analizată și în seria de publicații a ONU, World Population Ageing, in mai multe rapoarte din anii 2002, 2007, 2009, 2013, 2015, 2018, dar și în prognozele ONU, publicate în Revision of the World Population Prospects, 2017.

Obiectivele principale ale acestui articol urmăresc, pe de o parte, relevarea principalelor coordonate ale fenomenului îmbătrânirii populației din țara noastră în context global și european și repunerea în discuție a adecvării/suficienței politicilor adresate fenomenului îmbătrânirii populației din România, având în vedere prognoza fenomenului pe termen mediu și lung. În acest scop, vom utiliza date și informații cuprinse în unele articole şi studii de profil, dar și în unele publicații statistice sau ale unor instituții de specialitate ce țin sub observație acest fenomen.

\section{Tendințe ale îmbătrânirii demografice. Instituții și documente internaționale centrate pe gestionarea domeniului}

Potrivit World Population Prospects: the 2017 Revision (United Nations, 2017), la nivel mondial, numărul persoanelor în vârstă de 60 de ani și peste a crescut, tendință ce se va accentua în deceniile viitoare. Populația globală în vârstă de 60 de ani și peste - de 962 de milioane în anul 2017 - era de peste două ori mai ridicată decât în anul 1980 (382 de milioane). Este de așteptat ca populația vârstnică să se dubleze din nou înainte de anul 2050, când va atinge 2,1 miliarde de persoane. Populația de 80 de ani și peste va crește mai repede în masa totală al persoanelor vârstnice. Aceasta se va multiplica de trei ori în intervalul 20172050 - de la 137 la 425 de milioane.

Circa două treimi din populația vârstnică trăiește în regiunile în curs de dezvoltare, unde numărul acesteia crește mai rapid decât în regiunile dezvoltate. Prognoza ONU afirmă că în anul 2050, 8 din 10 persoane vârstnice vor trăi în regiunile în curs de dezvoltare (în Africa - creștere de 229\%, în America Latină și Caraibe - creștere de 161\%, în Asia - creștere de 132\%). 
Durata medie a vieții la nivel mondial, în anul 2015, era de 71,4 ani $-73,8$ ani pentru femei, 69,1 ani pentru bărbați. Țările din top erau Japonia, Elveția și Singapore cu o durată medie a vieții de peste 83 de ani. Cea mai scăzută speranță de viață la naștere - 50,1 ani - era înregistrată în anul 2015, în Sierra Leone (World Health Organization, 2016).

În intervalul 2010-2015, femeile au trăit mai mult decât bărbații, în medie cu 4,6 ani. În anul 2017, femeile generau $54 \%$ din populaţia mondială de 60 de ani şi peste, și $61 \%$ din populația de 80 de ani și peste. Durata medie de viață a bărbaților tinde să se apropie de cea a femeilor, astfel încât echilibrul genurilor în apropierea vârstei de 80 de ani să crească. Prognoza ONU prevede o scădere a proporției femeilor în vârstă de 80 de ani și peste cu 58\% în anul 2050 faţă de 2017. Proporția persoanelor în vârstă de 80 de ani și peste, la nivel global va crește de la $14 \%$ în anul 2017 la peste $20 \%$ în 2050 .

Numărul vârstnicilor crește mai rapid în urban decât în rural. În intervalul 2000-2015, numărul persoanelor de 60 de ani și peste a crescut cu $68 \%$ în zonele urbane, comparativ cu $25 \%$ în zonele rurale. Ca urmare, vârstnicii din urban tind să fie mai numeroși decât cei din rural. Fenomenul este mai accentuat pentru persoanele de 80 de ani și peste - proporția acestora în urban crescând de la 56\% în anul 2000 la 63\% în 2015.

În anul 2017, una din opt persoane, la nivel global, era în vârstă de 60 de ani și peste. În anul 2030, această proporție va deveni una la șase, iar în anul 2050 - una la cinci.

Începând din anul 2030, persoanele vârstnice vor depăși numeric copiii de 0-9 ani (1,41 miliarde versus 1,35 miliarde); din anul 2050, vor fi mai multe persoane de 60 de ani și peste decât adolescenți și tineri între 10 și 24 de ani $(2,1$ miliarde versus 2,0 miliarde).

Fenomenul îmbătrânirii este mai avansat în statele unde populația realizează venituri ridicate. Japonia deține în prezent populația cea mai îmbătrânită: $33 \%$ din populație era în vârstă de 60 de ani sau peste în anul 2017, fiind urmată de Italia (cu 29\%), Germania (28\%) și Portugalia (28\%). În anul 2017, 20 de țări înregistrau trei sferturi din populația vârstnică la nivel global. Aproape una din patru persoane în vârstă de 60 de ani sau peste trăiau în China. În cinci țări: China, India, Statele Unite, Japonia și Federația Rusă trăia jumătate din populația de 60 de ani sau peste și 48\% din populația de 80 de ani sau peste (World Health Organization, 2016).

Condiția umană la vârsta înaintată, statistic, presupune apariția unor situații de dependență economică și socială. Raportul general de dependență a generațiilor vârstnice în raport cu generațiile mai tinere devine tot mai tensionat. Vârstnicii pot trăi mai mult, dar tot mai puține persoane apte de muncă se constituie ca surse de sprijin pentru vârsta a III-a. Raportul de dependență a generațiilor succesive de vârstnici exprimă trebuințele de sprijin social și economic, prin intermediul familiei, al serviciilor comunitare, sau al unor transferuri financiare realizate prin asigurările și protecția socială. Asta deoarece nu toate persoanele 
vârstnice dispun de un potențial relevant pentru a se angaja în activități aducătoare de venituri după vârsta de 60-65 de ani. Analiza situației economice a vârstnicilor din diverse țări arată că, totuși, sunt și țări unde, vârsta cronologică pare a fi un predictor slab al gradului de dependență economică și socială ce poate afecta generațiile vârstnice.

La începutul anilor 1970, rata totală a dependenței globale atinsese un vârf de aproximativ 112 dependenți/100 de persoane în vârstă de muncă, apoi a scăzut treptat la 74/100, în 2017. Această rată va crește treptat în deceniile următoare. În anul 2030, va ajunge la 76/100, iar în 2050, la 79/100 (United Nations, 2017; World Population Ageing, 2017).

La nivel global, rata dependenței doar pentru persoanele vârstnice a început să crească de la mijlocul anilor 1980, când era de 12 persoane de 65 de ani sau peste/100 de persoane între 20 și 64 de ani. În anul 2017, această rată era de 15/100 urmând să crească până în anul 2050, la 28/100. Rata de dependență în rândul vârstnicilor a fost cea mai ridicată în regiunile cu cele mai mari ponderi ale persoanelor vârstnice în total populație. Pentru America de Nord, este prognozată o creștere abruptă a acestei rate de dependență, la nivelul a 40/100 după anul 2035. Raportul de dependență pentru vârstnici va crește în ritm accelerat și în Asia, America Latină și Caraibe, de la 14/100 în 2017 la 34/100 în America Latină și Caraibe și la 31/100 în Asia, până în anul 2050. Ponderea persoanelor în vârstă va crește mai lent în Africa, dar și în țările UE (United Nations, 2017; World Population Ageing, 2017).

\section{Prognoză demografică și politici sociale europene}

Parlamentul European a emis mai multe rezoluții, incusiv prin Carta drepturilor sociale (1989), vizând acest fenomen demografic. Consiliul European a adoptat mai multe decizii de profil, declarând anul 1993 „Anul european al persoanelor vârstnice" și a lansat principiul solidarității între generaţii ca bază a gestionării problematicii sociale generate de îmbătrânirea populaţiei europene. După anul 1995, Comisia a elaborat unele rapoarte demografice şi de analiză a protecţiei sociale. După anul 2000, pe această tematică, au avut loc conferințe europene, unde au fost puse în discuție perspectivele dezvoltării economice în relaţie cu trendurile demografice, ale ocupării în relație cu îmbâtrănirea demografică, ale consumului de servicii medicale. De asemenea, sunt intens dezbătute unele politici privind reorientarea productiilor de medicamente, sau pe tema reformelor aplicate în domeniul pensionării, ori a manifestării concrete a principiului solidarității dintre generaţii prin asistența socială ș.a.

Prognoza îmbătrânirii populațiilor europene. Societățile moderne și în special cele europene se remarcă prin progresul realizat în domeniul longevităţii populației. În ultimii 20 de ani, europenii au câștigat, în medie, cam 6 ani la speranța de viață. 
Populația din UE.28 va ajunge, potrivit prognozei din The 2018 Ageing Report, Economic and Budgetary Projections for the EU Member States (20162070) (European Commission, 2018), de la 511 milioane (2016) la 520 de milioane în anul 2070. Populația în vârstă de muncă (persoanele cu vârste între 15 și 64 de ani) va scădea semnificativ de la 333 milioane (2016) la 292 milioane în 2070. Modificările de structură ale populației au în vedere ipotezele cele mai probabile privind ratele de fertilitate, speranța de viață și fluxurile migratorii.

Până în anul 2030, circa $15,6 \%$ din populația globală (care este rezidentă în Europa) va avea 60 de ani sau peste, iar 23,1\% (rezidentă în Europa) va avea 80 de ani sau peste (tabel 1, tabel 2). Îmbătrânirea demografică va aduce schimbări semnificative în structura societăţilor europene, ceea ce va avea impact asupra economiei, sistemelor de securitate socială, sistemelor de sănătate, asupra pieței forței de muncă ș.a. 2050

Tabel 1. Persoane de 60 de ani și peste, la nivel global și european - 2017 - prognoză

\begin{tabular}{|c|c|c|c|c|c|c|c|c|c|c|}
\hline & \multicolumn{3}{|c|}{$\begin{array}{c}\text { Persoane în vârstă de } 60 \text { de ani și } \\
\text { peste (milioane) }\end{array}$} & \multicolumn{2}{|c|}{$\begin{array}{c}\text { Variația ponderii } \\
\text { (\%) }\end{array}$} & \multicolumn{3}{|c|}{$\begin{array}{c}\text { Distribuția persoanelor în vârstă de } \\
60 \text { de ani și peste (\%) }\end{array}$} \\
\cline { 2 - 11 } & 1980 & 2017 & 2030 & 2050 & $\begin{array}{c}1980- \\
2017\end{array}$ & $\begin{array}{c}2017- \\
2050\end{array}$ & 1980 & 2017 & 2030 & 2050 \\
\hline $\begin{array}{c}\text { Nivel } \\
\text { mondial }\end{array}$ & 382,5 & 962,3 & $1.406,1$ & $2.080,5$ & 151,6 & 116,2 & 100,0 & 100,0 & 100,0 & 100,0 \\
\hline Europa & 111,2 & 183,0 & 218,8 & 247,2 & 64,5 & 35,1 & 29,1 & 19,0 & 15,6 & 11,9 \\
\hline
\end{tabular}

Sursa: United Nations, 2017, World Population Prospects: The 2017 Revision, World Population Ageing, 2017, Department of Economic and Social Affairs, Population Division, United Nations, New York.

Tabel 2. Persoane de 80 de ani și peste, la nivel global și european - 2017 - prognoză 2050

\begin{tabular}{|c|c|c|c|c|c|c|c|c|c|c|}
\hline & \multicolumn{3}{|c|}{$\begin{array}{c}\text { Persoane în vârstă de } 80 \text { de ani și } \\
\text { peste (milioane) }\end{array}$} & \multicolumn{3}{|c|}{$\begin{array}{c}\text { Variația ponderii } \\
\text { (\%) }\end{array}$} & \multicolumn{3}{|c|}{$\begin{array}{c}\text { Distribuția persoanelor în vârstă de } \\
80 \text { de ani și peste (\%) }\end{array}$} \\
\cline { 2 - 12 } & 1980 & 2017 & 2030 & 2050 & $\begin{array}{c}1980- \\
2017\end{array}$ & $\begin{array}{c}2017- \\
2050\end{array}$ & 1980 & 2017 & 2030 & 2050 \\
\hline $\begin{array}{c}\text { Nivel } \\
\text { mondial }\end{array}$ & 35,8 & 137,3 & 201,9 & 424,7 & 283,3 & 209,3 & 100,0 & 100,0 & 100,0 & 100,0 \\
\hline Europa & 13,9 & 37,5 & 46,6 & 72,5 & 169,2 & 93,5 & 38,8 & 27,3 & 23,1 & 17,1 \\
\hline
\end{tabular}

Sursa: United Nations, 2017, World Population Prospects: The 2017 Revision, World Population Ageing, 2017, Department of Economic and Social Affairs, Population Division, United Nations, New York. 
Prognozele indică o menținere a tendinței de creștere a speranței de viață, pe fondul progreselor medicale fără precedent și a standardului de viață tot mai ridicat.

Media speranței de viață la naștere în țările UE.28 a crescut în ultimele patru decenii, dar creșterea a încetinit, după anul 2010, în mai multe țări din Occident. Speranța de viață la naștere a atins 81 de ani în UE.28, adică peste 80 de ani în două treimi din statele UE.28.

$\mathrm{Cu}$ toate că la nivelul Uniunii Europene s-au realizat progrese semnificative în domeniul calității ofertei de servicii medicale și ocrotirii sănătății populației, există în continuare mari decalaje în ceea ce privește speranța de viață între țările membre. În anul 2016, Spania și Italia înregistrau valori peste 83 de ani, dar țări precum România, Bulgaria, Letonia sau Lituania oscilau încă în jurul valorii de 75 de ani. Statistic, femeile trăiesc mai mult decât bărbații, în medie cu aproximativ 5,5 ani, decalaje între genuri mult mai mari - în jur de 10 ani - înregistrându-se în România și Bulgaria. Asemenea decalaje persistă, în special, din cauza expunerii populației masculine din țările respective, la un consum crescut de tabac, alcool, sau a practicării unor diete alimentare mai puțin sănătoase, dar și pe fondul unui grad general mai ridicat al stresului de domeniu economic și ecologic (OECD, EU, 2018).

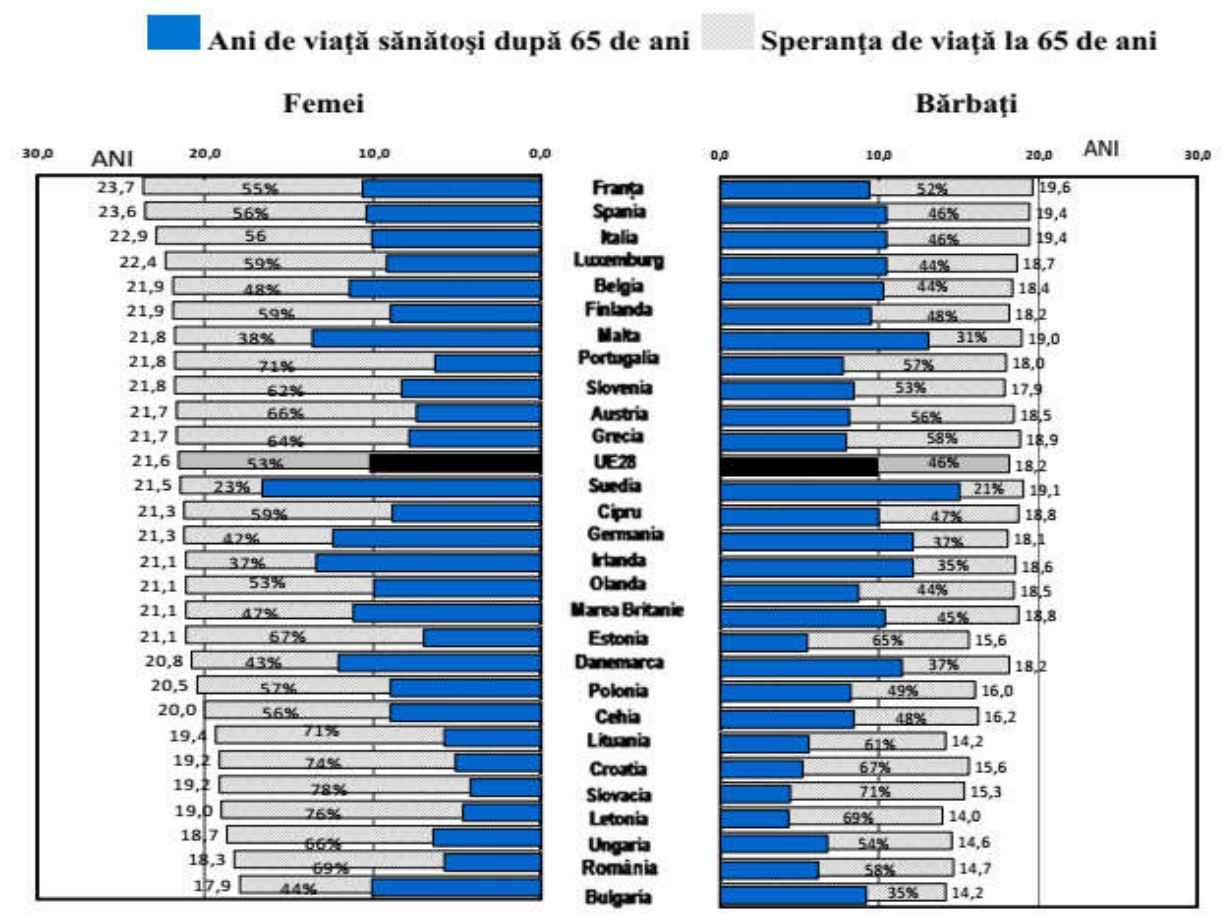

Figura 1: Speranța de viață și ani de viață sănătoși la 65 de ani, în funcție de gen, 2016, în țările UE.28 
La nivelul mediei UE.28, în anul 2016, femeile de 65 de ani înregistrau o speranță de viață de 21,6 ani, din care $\mathbf{4 7 \%}$ erau ani de viață sănătoși, iar bărbații de 65 de ani, deși înregistrau o speranță de viață mai redusă decât femeile - 18,2 ani, 54\% din acești ani erau ani de viață sănătoși (Figura 1).

Politici sociale adresate îmbătrânirii populației din UE.28. Evoluțiile demografice din țările UE.28 vor genera schimbări în multe domenii ale politicilor sociale: în politicile familiale, în politicile de educație și învățare permanentă, în politicile piețelor forței de muncă, în protecția socială și sistemele de pensii, în politicile de sănătate și asistență medicală, în politicile de asistență socială ș.a. În asemenea domenii se vor realiza cheltuieli semnificative, susținute prin fonduri specializate de tip contributiv sau prin bugetele publice. Ca urmare, îmbătrânirea populației este și va fi periodic examinată din perspectiva sustenabilității financiare, iar rezultatele vor fi integrate în cadrul unor prognoze de către instituții specializate ale Comisiei Europene. Recent, pe această temă, Comisia Europeană a publicat The 2018 Aging Report Economic \& Budgetary Projections for the 28 EU Member States (2016-2070) Institutional Paper 079, May 2018. Politicile ce vizează îmbătrânirea populației susținute încă din 2001 de Consiliul European de la Stockholm au avut trei priorități: (i) reducerea rapidă a datoriei naționale publice; (ii) creșterea ratei de ocupare a forței de muncă și a productivității muncii; (iii) reformarea sistemelor de pensii, a sistemelor de îngrijire a sănătății și de asistență socială. Pentru prima dată, Consiliul European de la Stockholm a definit un obiectiv cantitativ ambițios în acest sens, pe care 1-a și atins: o creștere a ratei de ocupare a persoanelor în vârstă la 50\% până în anul 2010 (de la 26,3\% în anul 2000). Și la Consiliul European de la Barcelona s-a afirmat în mod tranșant că responsabilitatea pentru abordarea problemelor legate de îmbătrânirea populației va trebui împărțită între generații, acționându-se totodată, în sensul creșterii progresive cu aproximativ 5 ani a vârstei medii efective la care oamenii nu mai lucrează în Uniunea Europeană, până în 2010. Evaluarea din anul 2004 efectuată de Comisia Europeană privind „Creșterea gradului de ocupare a forței de muncă în rândul lucrătorilor în vârstă și întârzierea ieșirii de pe piața muncii" a arătat că progresele înregistrate în domeniu au fost totuși insuficiente, în unele state, iar statele membre au fost invitate să dezvolte strategii mai cuprinzătoare de îmbătrânire activă, pentru a ieși din cultura politicilor de pensionare anticipată.

UE a lansat, în anul 2005, Cartea verde a UE privind schimbările demografice (Comisia Europeană, 2005). Problema acordării unor îngrijiri neadecvate la cerințele pieței muncii, cât și la trebuințele de îngrijire ale celor aflați în nevoie pot genera obstacole insurmontabile în calea unei mai bune utilizări a resurselor umane și pot împiedica creșterea economică. Politicile UE de pe piața muncii au în vedere mobilizarea tuturor resurselor umane, în sensul unei mai bune reconcilieri a vieții profesionale cu viața de familie. Încă de la sfârșitul anilor 1990, reconcilierea dintre muncă și familie a fost integrată în strategia europeană de ocupare a forței de muncă. Importanța unor asemenea politici a fost confirmată și în anul 2000 în cadrul Strategiei de la Lisabona. Consiliul European din martie 2005 a subliniat 
posibilele consecințe pozitive ale reconcilierii măsurilor de muncă și de viață familială cu participarea mai largă a femeilor și a persoanelor vârstnice pe piața forței de muncă. Valorificarea potențialului de muncă al tuturor generațiilor, inclusiv al populației în vârstă, poate contribui la dezvoltarea economică și bunăstarea din UE și din statele membre.

În anul 2006, Comisia Europeană a afirmat în ,Viitorul demografic al Europei - de la provocare la oportunitate” că „Având în vedere complexitatea provocărilor îmbătrânirii, o strategie globală pare a fi esențială. Atât la nivelul UE, cât și la nivel național, va fi necesară revizuirea politicilor existente pentru a determina dacă acestea trebuie adaptate" (Comisia Europeană, 2006, 7). Documentul formulează mai multe politici adecvate aplicabile la nivel național și comunitar, după cum urmează:

1. sprijinirea reînnoirii demografice prin crearea unor condiții mai bune de viață pentru familii și prin reconcilierea vieții profesionale cu viața de familie;

2. stimularea ocupării forței de muncă prin înființarea a mai multe locuri de muncă, ceea ce va contribui la o durată de viață mai lungă și mai bună;

3. creșterea productivității și a performanței economice prin investiții în educație și cercetare;

4. primirea și integrarea imigranţilor în societatea europeană;

5. asigurarea finanțelor publice sustenabile pentru a garanta pensii adecvate, asistență medicală și îngrijire pe termen lung.

O rezoluție a Consiliului Europei privind „Oportunitățile și provocările schimbărilor demografice în Europa: contribuția persoanelor în vârstă la dezvoltarea economică și socială", adoptată la 22 februarie 2007, a subliniat necesitatea de a mări participarea persoanelor în vârstă, inclusiv prin muncă voluntară, și prin crearea de noi perspective de participare economică (,economia de argint”) a persoanelor vârstnice, accentuând importanța consolidării unei imagini publice pozitive a persoanelor în vârstă.

Până în prezent, la nivelul UE, sute de milioane de euro au fost investite, în cercetarea privind impactul îmbătrânirii populației în domeniul sănătăţii, al extinderii bolilor neurodegenerative și al dezvoltării socio-economice. Cercetările de acest gen au fost incluse în Programul Orizont 2020. Îmbătrânirea activă şi sănătoasă, precum și menținerea independenței socio-economice a persoanelor în vârstă reprezintă o provocare pentru toate statele europene. Acest lucru creează noi oportunități de a gândi creativ și a inova tehnologii, servicii sau noi modele de afaceri centrate pe satisfacerea trebuințelor persoanelor vârstnice. Acest obiectiv stă la baza „Parteneriatului european pentru inovare privind îmbătrânirea activă și în condiții bune de sănătate” lansat de Comisia Europeană în anul 2011, spre a face față provocărilor induse de schimbările demografice.

Protecție socială și prognoză privind cheltuielile pentru susținerea politicilor adresate îmbătrânirii demografice. Sistemele de protecție socială generează instrumentele de bază în gestionarea schimbărilor induse de 
îmbătrânirea demografică. Acestea au rolul de a ține sub control riscul de sărăcie şi de îmbolnăvire, mărind coeziunea socială. Eficacitatea sistemelor de protecție socială în contextul schimbărilor demografice reprezintă o provocare pentru orice guvern care trebuie să garanteze asigurarea prosperității într-o societate aflată în îmbătrânire pe scară socială largă. Metoda deschisă de coordonare (MDC), dezvoltată pentru a ajuta guvernele naționale în elaborarea unor astfel de politici și strategii, vizează organizarea unui proces voluntar de cooperare în domeniul politicilor sociale, bazat pe obiective comune convenite și pe indicatori comuni ce vor sta la baza evaluării atingerii obiectivelor fixate. Scopul acestei metode este acela de a dezvolta un proces de învățare reciprocă, prin examinarea unor politici, programe sau aranjamente instituționale specifice, prezentate drept bune practice.

Îmbătrânirea populației este monitorizată și din perspectiva politicilor economice. Comisia Europeană analizează performanțele statelor europene în sfera bunăstării sociale, acordând o atenție specială implicațiilor economice și bugetare ale îmbătrânirii populației. Proiecțiile privind cheltuielile legate de necesitatea finanțării sistemelor de pensii, a asigurării asistenței medicale și asistenței sociale pe termen lung generează dezbateri intense la nivelul UE.28. Periodic sunt pregătite rapoarte demografice și prognoze actualizate. Prognoza Comisiei Europene în privința îmbătrânirii demografice din UE pornește de la supoziția unei rate medii relative scăzute de creștere a PIB-ului European pe termen lung - 1,2\% până în anul 2040 şi $1,5 \%$ în intervalul 2040-2070, adică 1,4\% pentru întregul interval 2016-2070 (1,3\% pentru Zona Euro) (EC, 2018). Potrivit Scenariului de Bază al proiecțiilor Comisiei Europene, impactul fiscal al îmbătrânirii populației va fi semnificativ în aproape toate statele membre ale UE, efectele devenind vizibile în următoarele două decenii. Cele mai mari incertitudini vizează cheltuielile din sfera serviciilor medicale și din serviciile de îngrijire pe termen lung (EC, 2018). Scenariul de Bază al CE care a proiectat un cost total al fenomenului îmbătrânirii populației europene de 25\% din PIB-ul mediu European, în anul 2016, susține că acest cost va crește cu 1,7 puncte procentuale din PIB-ul mediu European până în anul 2070. (Pentru Zona Euro, față de 26\% din PIB în 2016, cheltuielile vor crește cu 1,1 puncte procentuale până în anul 2070). Cele mai mari cheltuieli vor fi efectuate până în anul 2040, acestea rezultând în principal din trebuințele primare ale sistemelor de pensii. Diminuarea necesarului de fonduri în acest domeniu, potrivit proiecției CE va deveni posibilă abia după trei decenii de creștere. Trei grupuri distincte de țări s-au conturat în această privință: în opt state cheltuielile proiectate vor scădea cu peste 3 puncte procentuale - Grecia, Croația, Franța, Lituania, Italia, Letonia, Estonia, și Spania; într-un alt grup cheltuielile vor crește moderat cu până la 3 puncte procentuale - Portugalia, Danemarca, Cipru, Polonia, Suedia, România, Bulgaria, Finlanda, Ungaria și Slovacia; în zece state cheltuielile vor crește cu mai mult de 3 puncte procentuale din PIB Olanda, Austria, Irlanda Germania, M. Britanie, Belgia, R. Cehă, Slovenia, Malta, Luxemburg. Cheltuielile prevăzute să crească cel mai mult până în anul 2070 sunt cele pentru servicii medicale și servicii de îngrijire pe termen lung, care împreună 
vor crește cu 2,1 puncte procentuale din PIB (îngrijirea pe termen lung cu 1,2, iar serviciile medicale cu 0,9 puncte procentuale). După o creștere a cheltuielilor pentru pensiile publice de 0,8 pcte procentuale din PIB până în anul 2040, este proiectată o revenire la nivelul din 2016 (UE: - 0,2 pcte procentuale).

Cheltuielile publice pentru pensii vor crește până în anul 2040, după care vor reveni foarte aproape de nivelul actual până în anul 2070. Se estimează că reformele aplicate până în prezent în domeniul pensiilor vor permite stabilizarea cheltuielilor publice pentru pensii ca pondere din PIB pe termen lung, în special ca urmare a majorării vârstei de pensionare, a modificării parametrilor sistemelor de pensii sau ca urmare a indexării pensiilor.

Tabel 3. Proiecții ale dinamicii cheltuielilor bugetare corelate cu vârsta/îmbătrânirea populației - media UE.28 (2016-2070), pe capitole de cheltuieli (puncte procentuale din PIB)

\begin{tabular}{|c|c|c|c|c|c|c|c|c|c|c|c|c|}
\hline & \multicolumn{3}{|c|}{ Pensii } & \multicolumn{3}{|c|}{ Sănătate } & \multicolumn{3}{|c|}{$\begin{array}{l}\text { Îngrijire pe } \\
\text { termen lung }\end{array}$} & \multicolumn{3}{|c|}{$\begin{array}{c}\text { Itemi corelați } \\
\text { strict cu } \\
\text { îmbătrânirea } \\
\text { populației }\end{array}$} \\
\hline An(ii) & $\begin{array}{l}\stackrel{0}{0} \\
\stackrel{\sim}{N}\end{array}$ & 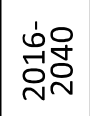 & 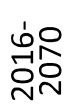 & $\begin{array}{l}0 \\
\stackrel{0}{0}\end{array}$ & 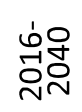 & 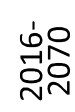 & $\begin{array}{l}0 \\
\stackrel{\sim}{0}\end{array}$ & 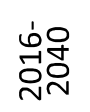 & 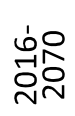 & $\begin{array}{l}\stackrel{0}{1} \\
\stackrel{\sim}{N}\end{array}$ & 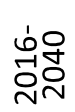 & $\begin{array}{l}\text { ம்o } \\
\text { 윰 }\end{array}$ \\
\hline $\begin{array}{l}\text { Medie } \\
\text { UE.28 }\end{array}$ & 11,2 & $+0,8$ & $-0,2$ & 6,8 & $+0,6$ & $+0,9$ & 1,6 & $+0,6$ & $+1,2$ & 24,1 & $+2,0$ & $+1,8$ \\
\hline
\end{tabular}

\begin{tabular}{|c|c|c|c|c|c|c|c|c|c|}
\hline & \multicolumn{3}{|c|}{ Educație } & \multicolumn{3}{|c|}{$\underset{\text { șomaj }}{\text { Indemnizatie de }}$} & \multicolumn{3}{|c|}{ Total itemi corelați cu vârsta } \\
\hline An(ii) & $\begin{array}{l}\stackrel{0}{1} \\
\stackrel{\nu}{\nu}\end{array}$ & 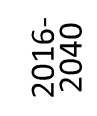 & $\begin{array}{l}\text { bेo } \\
\text { 䓟 }\end{array}$ & $\begin{array}{l}0 \\
\stackrel{1}{N}\end{array}$ & 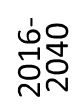 & 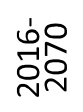 & $\begin{array}{l}0 \\
\stackrel{\sim}{\sim}\end{array}$ & 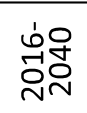 & 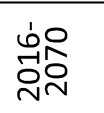 \\
\hline $\begin{array}{l}\text { Medie } \\
\text { UE. } 28 \\
(\%)\end{array}$ & 4,5 & $-0,1$ & +0 & 0,8 & $-0,2$ & $-0,2$ & 25,0 & $+1,8$ & $+1,7$ \\
\hline
\end{tabular}

Sursa: European Commission, The 2018 Aging Report Economic and Budgetary Projections for the 28 EU Member States (2016-2070), Institutional Paper 079, May 2018

În The 2018 Ageing Report se preconizează ca pensia publică medie să scadă în medie cu 10,6 puncte procentuale față de salariul mediu, la nivelul UE. În statele 
membre cu sisteme de pensii private suplimentare, valoarea totală a pensiilor în raport cu salariile medii se preconizează a fi cu 10,5 puncte procentuale mai mare decât în statele membre fără. În plus, este de așteptat ca vârstele de pensionare să mai crească în viitor în toate statele UE.

Cheltuielile pentru sănătate vor crește cu 0,6 puncte procentuale până în 2040, dar cu 0,9 puncte procentuale per total până în anul 2070.

Cheltuielile de îngrijire pe termen lung (asistența socială) și îngrijirea sănătății vor contribui per total cu 1,2 puncte procentuale din media PIB al UE.28 la creșterea cheltuielilor legate de fenomenul îmbătrânirii populației până în anul 2070.

Itemii corelați strict cu îmbătrânirea populației (per total) vor contribui totuși cel mai mult la creșterea cheltuielilor bugetare - cu 2,0 puncte procentuale până în anul 2040 - adică cu 1,8 puncte procentuale din media PIB UE.28, pe întreaga perioadă până în anul 2070.

\section{Caracteristici ale îmbătrânirii populației din România}

În România anului 2016, populaţia de 65 de ani sau peste depăşea cu 350.000 de persoane populaţia de 0-14 ani, potrivit Institutului Naţional de Statistică (Andrei, 2018). Comparativ cu 1 ianuarie 2017, la 1 ianuarie 2018, a avut loc o scădere a ponderii persoanelor tinere ( $0-14$ ani) şi o creştere cu 0,3 puncte procentuale a populaţiei de 65 de ani sau peste. Indicele de imbătrânire demografică a crescut de la 107,9, la 1 ianuarie 2017, la 110,7 persoane vârstnice/100 de persoane tinere, la 1 ianuarie 2018. Populaţia României, după criteriul domiciliului, a scăzut la 22,194 milioane de persoane la 1 ianuarie 2018, fiind cu $0,2 \%$ mai mică faţă de 1 ianuarie 2017. Populaţia urbană, ca și aceea de gen feminin sunt majoritare (56,4\%, respectiv 51,2\%) (INSSE, 2018). La 1 ianuarie 2018, populaţia după domiciliu din urban era de 12,508 milioane de persoane, în scădere cu 0,1\% faţă de 1 ianuarie 2017. Populaţia feminină la 1 ianuarie 2018 era de 11,358 milioane de persoane, în scădere cu $0,2 \%$ faţă de anul precedent.

Vârsta medie a populaţiei din România a crescut, la 1 ianuarie 2018, fiind de 41,3 ani, cu 0,2 ani mai mare decât la 1 ianuarie 2017. Vârsta mediană era de 41,2 ani - cu 0,4 ani mai mare decât la 1 ianuarie 2017. O asemenea vârstă medie caracterizează ţările cu populaţie ,adultă”. Cea mai mare pondere în totalul populației, la 1 ianuarie 2018 era înregistrată de grupa $45-49$ de ani $(8,6 \%-8,8 \%$ masculin, 8,3\% feminin). Grupa $0-4$ ani reprezenta $4,6 \%$ din total populație.

Speranța de viață la naștere a populației din România - 75,3 ani - prezintă un decalaj de 6-7 ani față de statele vest europene, situându-se cu 5,9 ani sub media europeană. 
Tabel 4. Evoluția speranţei de viaţă la naştere pentru populația totală în România

\begin{tabular}{|l|c|c|c|}
\hline \multicolumn{1}{|c|}{ Perioada } & Populație totală & Perioada & Populație totală \\
\hline 1900 & 36,40 ani & $2006-2014$ & De la 73,47 la 75,44 ani \\
\hline $1974-1975$ & 69,3 ani & 2015 & 75,39 ani \\
\hline $1998-2000$ & Peste 70,00 & 2016 & 75,56 ani \\
\hline 2011 & 73,98 ani & 2017 & 75,40 ani \\
\hline
\end{tabular}

Notă: Speranţa de viaţă la naştere în anul de referinţă s-a calculat pe baza numărului populaţiei după domiciliu şi al decedaţilor cu domiciliul sau reşedinţa obişnuită în România. Indicatorul speranța de viață la naștere se referă la populaţia în funcție de domiciliu.

Surse: Andrei, coord., 2018, INS; Comper, 2011; Vulea, 2018

Tabel 5. Speranța de viață în funcție de gen - România comparativ cu UE.28

\begin{tabular}{|l|c|c|c|}
\hline & Anul & Media UE.28 & Media României \\
\hline Speranța de viață la naștere & 2017 & f. 83,5 ani; b. 78,3 ani & f. 79,1 ani; b. 71,7 ani \\
\hline $\begin{array}{l}\text { Speranța de viață la vârsta de } \\
65+\text { ani }\end{array}$ & 2017 & f. 21,4 ani; b. 18,1 ani & f. 18,3 ani; b. 14,7 ani \\
\hline $\begin{array}{l}\text { Speranța de viață sănătoasă la } \\
65+\end{array}$ & 2016 & f. 10,1 ani; b. 9,8 ani & f. 5,6 ani; b. 6,2 ani \\
\hline
\end{tabular}

Surse: Eurostat, 2018, A look at the lives of the elderly in the EU today, Life expectancy at birth by sex; Eurostat, 2019, Healthy life years and life expectancy at age 65 by sex.

România înregistrează a patra speranță de viață la naștere scăzută din UE - 75,4 ani, față de media UE.28 de 81 de ani, dar și cele mai mici cheltuieli cu sănătatea din UE.28, potrivit Raportului Sănătatea pe scurt: Europa, Comisia Europeană (OECD și EU, 2018). În România se înregistrează un decalaj mare între speranţa de viaţă a bărbaților (71,7 ani) și cea a femeilor (79,1 ani), diferențe mai mari, de peste 10 ani, fiind înregistrate în Letonia şi Lituania.

Speranța de viață la 65 de ani. Cunoașterea speranței de viață la anumite vârste oferă unele repere utile pentru configurarea unor politici socio-economice, în domenii precum politicile de ocupare a forței de muncă, politicile de pensionare, politicile din domeniul îngrjirii sănătății.

Pentru femei, speranța de viață la 65 de ani este de 18,02 ani, în timp ce pentru bărbați este de 14,68 ani (INS, 2014, în Redactia Alba24.ro, 2016). Speranța de viață la 65 de ani, în perioada 1970-2014, a crescut cu circa 2 ani în cazul bărbaților, şi cu 3,6 ani în cel al femeilor.

Speranța de viață sănătoasă. În perioada 2007-2014, cu toate că a crescut durata medie a vieții, atât la bărbați cât și la femei, speranța de viață sănătoasă a scăzut, de la 62,5 ani la 59 de ani pentru femei și de la 60,5 ani la 59 de ani pentru 
bărbați. Față de mediile din UE (de 61,4 ani la bărbați și 61,8 ani la femei), speranța de viață sănătoasă la naștere din România este mai mică - cu 2,4 ani pentru bărbați și cu 2,8 ani pentru femei.

Situația este similară pentru speranța de viață sănătoasă pentru persoanele de 65 de ani, aceasta fiind de 5,7 ani pentru femei și 5,9 ani pentru bărbați, comparativ cu 8,6 ani pentru ambele sexe la nivelul mediei UE-28 (Redacția Alba24.ro, 2016).

România înregistrează a doua rată ridicată a mortalității din UE.28, după Bulgaria - de 1.530 decese/100.000 locuitori, față de o medie UE.28 de 1.036/10.000. Cea mai frecventă cauză de deces - bolile sistemului circulator (cardiovasculare, cerebrovasculare). România se află pe ultimul loc în UE.28 la cheltuielile pentru sănătate, cu 983 euro anual pe locuitor, mai puțin cu 250 euro decât Bulgaria. La polul opus se află Luxemburg, cu 4.713 euro, în timp ce media UE.28 este de 2.773 euro (Andrei, coord., 2018). Ratele mortalităţii specifice pe cauze de deces din România diferă pe sexe. Mortalitatea feminină are valori superioare celei masculine în cazul bolilor aparatului circulator, al bolilor endocrine, de nutriţie şi metabolism, al bolilor sistemului nervos şi al bolilor aparatului genito-urinar. Pentru alte cauze de deces se manifestă o „supramortalitate masculină" mai accentuată în cazul tumorilor, leziunilor traumatice, otrăvirilor şi a altor consecinţe ale cauzelor externe, ale bolilor aparatului respirator şi ale bolilor aparatului digestiv. Decesele înregistrate în anul 2016 au continuat să aibă ca principale cauze bolile aparatului circulator $57,8 \%$ (în principal boala ischemică a inimii $19,3 \%$ şi bolile cerebro-vasculare $16,7 \%)$ şi tumorile $(20,1 \%)$. Decesele datorate acestor două cauze au reprezentat $77,9 \%$ din totalul deceselor. Comparativ cu 2015, în anul 2016 s-a menţinut ordinea principalelor cauze de deces, pe primul loc situându-se bolile aparatului circulator, urmate de tumori, bolile aparatului respirator $(5,7 \%)$ şi bolile aparatului digestiv $(5,6 \%)$. Datorită nivelului diferenţiat al mortalităţii pe medii de rezidenţă înregistrat şi în anul 2016, durata medie de viaţă a populaţiei din mediul urban a fost superioară celei din mediul rural, cu 2,76 ani. Pentru ambele sexe, durata medie a vieţii în mediul urban a fost mai mare decât cea din rural. Diferenţe mai accentuate s-au înregistrat la populaţia masculină (3,14 ani) faţă de cea feminină (1,79 ani) (Andrei, coord., 2018). Toate acestea survin pe fondul unui deficit masiv de fonduri alocate dezvoltării resurselor umane, sectorului social și în special sistemului public de servicii medicale. Unul din cinci români - 20 puncte procentuale, cu vârsta între 20 și 64 de ani trăiește în prezent într-o țară din Uniunea Europeană, în timp ce, la nivelul țărilor din UE.28, media acestui indicator este de 3,8 puncte procentuale. 


\section{Condițiile de viață ale vârstnicilor din România}

Cele două categorii distincte de populație vârstnică - 65-79 de ani și 80 sau peste - au probleme comune, dar pot avea și probleme specifice. Politicile adresate acestora trebuie să țină seama de ponderea persoanelor vârstnice aflate în risc de sărăcie/deprivare materială severă în fiecare categorie de vârstă în prezent, dar și de necesitatea prevenirii ajungerii într-o situație de risc în viitor. Factorii ce pot schimba nivelul de bunăstare socială al persoanelor vârstnice pot fi numeroși, decurgând din situația socială a persoanelor respective, din situația locuirii lor, din starea lor de sănătate, din nivelul de educație, din standardul lor de viață actual, dar și din nivelul de dezvoltare sau standardul de viață al comunității în general.

Tabel 6. Factori ce pot influența condițiile de viață ale persoanelor vârstnice

\begin{tabular}{|l|c|c|c|}
\hline & Anul & Media în UE.28 & Media în România \\
\hline Pondere populație vârstnică în total populație & 2016 & $19,2 \%$ & $17,4 \%$ \\
\hline Populație de 65+ care trăiește singură & 2015 & $32,1 \%$ & $35,6 \%$ \\
\hline Populație de 65-74 ani economic activă încă & 2016 & $9,5 \%$ & $15,0 \%$ \\
\hline Populație de 65+ ani care călătorește & 2015 & $48,8 \%$ & $13,5 \%$ \\
\hline $\begin{array}{l}\text { Populație de 65+ care utilizează internetul cel puțin o } \\
\text { dată pe săptămână }\end{array}$ & 2015 & $45 \%$ & $13 \%$ \\
\hline
\end{tabular}

Sursa: Eurostat, 2018, A look at the lives of the elderly in the EU today, Life expectancy at birth by sex.

Din cei câțiva indicatori cupruinți în tabelul 5 observăm decalajele mari existente între condițiile de viață ale populației din România comparative cu media UE.28. Asta deoarece în România, unele riscuri ale îmbătrânirii populației nu sunt recunoscute social şi ca urmare nu sunt finanțate prin politici social-economice corespunzătoare. Principalele consecințe ale procesului de îmbătrânire a populației din România vizează:

- problemele ce decurg din dependența economică a unor categorii de vârstnici (sărăcie, deprivare materială severă, lipsa unei locuințe sau venituri insuficiente);

- dependența familială problematică a unor vârstnici cu grad limitat de autonomie în exercitarea vieții personale (lipsa unor membri de familie aparținători, abandon familial ș.a.);

- deficitul de satisfacere a unor trebuințe de servicii pentru populaţia vârstnică (acces dificil la serviciile medicale sau la serviciile comunitare de îngrijire pe termen lung);

- dificultăți de finanțare a pensiilor, ajutoarelor sociale și altor forme de sprijin. 
Indicatorii monitorizați până în prezent în cadrul UE.28 cu privire la standardul de viață al populației de $65+$ ani arată persistența unor decalaje consistente între generațiile de vârstnici din România și cei din UE. Iată de ce o pondere mult mai ridicată a populației vârstnice din România continuă să fie economic activă după vârsta pensionării, spre deosebire de populația din UE.28 care preferă (și își poate permite), într-o proporție mult mai mare - $48,8 \%$ față de $13,5 \%$ - să călătorească. Evoluția persoanelor inactive, pe tranșe de vârstă, ca procent din total populație inactivă indică o descreștere relativă a populației inactive de 60 de ani sau peste, de la $32,5 \%$ (1992) la 27,7\% (2002) și o oarecare revenire la 31,7\% (2011) din total populație inactivă.

Tabel 7. Pondere persoane inactive, pe grupe de vârstă, în total persoane inactive, la recensămintele din anii 1992, 2002 şi 2011

\begin{tabular}{|l|c|c|c|}
\hline Categorii de populație (\%) & 1992 & 2002 & 2011 \\
\hline $0-14$ ani & 49,4 & 32,5 & 29,2 \\
\hline $15-59$ de ani & 18,1 & 39,8 & 39,1 \\
\hline 60 de ani sau peste & 32,5 & 27,7 & 31,7 \\
\hline
\end{tabular}

Sursa: Recensământul populației şi al locuinţelor, în anii 1992-2011, CNS, INS

Și indicatorii generali ai standardului de viață sunt grăitori în acest sens, cei mai importanți fiind riscul de sărăcie, deprivarea materială severă, nivelul veniturilor populației vârstnice ș.a. Declinul economic masiv din ultimele trei decenii a afectat sensibil o mare parte din generațiile ce au atins vârsta pensionării după 1990 și potrivit prognozei, va crea în continuare probleme, pe linia asigurării unei protecții economico-sociale adecvate, persoanelor vârstnice.

Tabel 8. Veniturile brute ale populației de 65 de ani și peste, în România, 2015, 2016

\begin{tabular}{|c|c|c|c|c|}
\hline Anul & $\begin{array}{c}\text { Venituri } \\
\text { lunare } \\
\text { medii/ } \\
\text { gospodărie } \\
\text { (lei) }\end{array}$ & $\begin{array}{c}\text { Veniturile lunare } \\
\text { medii/persoană } \\
\text { (lei) }\end{array}$ & $\begin{array}{c}\text { Pondere venituri } \\
\text { lunare medii/ } \\
\text { gospodărie în } \\
\text { veniturile totale ale } \\
\text { gospodăriilor }\end{array}$ & $\begin{array}{c}\text { Pondere venituri } \\
\text { lunare medii/persoană } \\
\text { în veniturile totale/ } \\
\text { persoană }\end{array}$ \\
\hline 2015 & $2.040,2$ & 940,8 & 75,9 & 93,1 \\
\hline 2016 & $2.151,0$ & 998,9 & 73,0 & 89,8 \\
\hline
\end{tabular}

Sursa: Andrei, coord., 2018

În România anului 2017 trăiau în jur de 5,22 milioane de pensionari, dispunând de o pensie medie lunară de 1.022 lei. Raportul dintre numărul mediu de pensionari de asigurări sociale de stat şi cel al salariaţilor era, în anul 2017, de 9 la 10, dar acesta prezenta variaţii semnificative de la o regiune la alta - de la numai 5 
pensionari la 10 salariaţi în Bucureşti, la 17 pensionari la 10 salariați în judeţul Teleorman.

Tabel 9. Veniturile disponibile (nete), ale pensionarilor comparativ cu alte categorii de gospodării, în anul 2016

\begin{tabular}{|l|c|c|c|c|c|c|}
\hline $\begin{array}{c}\text { Venituri } \\
\text { disponibile }\end{array}$ & $\begin{array}{c}\text { Total } \\
\text { gospodării }\end{array}$ & Salariați & $\begin{array}{c}\text { Lucrători pe } \\
\text { cont propriu } \\
\text { in activități } \\
\text { neagricole }\end{array}$ & Agricultori & Şomeri & Pensionari \\
\hline $\begin{array}{l}\text { - medii } \\
\text { lunare/ } \\
\text { gospodărie, } \\
\text { lei }\end{array}$ & $2.314,3$ & $2.984,6$ & $2.026,2$ & $1.589,8$ & $1.622,0$ & $1.860,5$ \\
\hline $\begin{array}{l}\text { - medii } \\
\text { lunare/ } \\
\text { persoană, lei }\end{array}$ & 874,2 & $1.039,0$ & 578,4 & 466,2 & 494,6 & 864,0 \\
\hline $\begin{array}{l}\text { În \% față de total gospodării: } \\
100,0\end{array}$ & 129,0 & 87,5 & 68,7 & 70,1 & 80,4 \\
\hline $\begin{array}{l}- \text { medii } \\
\text { lunare pe o } \\
\text { gospodărie }\end{array}$ & 100,0 & 118,9 & 66,2 & 53,3 & 56,6 & 98,8 \\
\hline $\begin{array}{l}\text { - medii } \\
\text { lunare pe o } \\
\text { persoană }\end{array}$ & & & & & & \\
\hline
\end{tabular}

Sursa: Andrei, coord., 2018

Prestaţiile sociale au format $46,7 \%$ respectiv $37,6 \%$ din veniturile băneşti ale gospodăriilor alcătuite din una, respectiv două persoane, cea mai mare parte a lor venind din pensii. Ponderea prestaţiilor sociale (în special a pensiilor) a fost mult mai mare în veniturile băneşti ale gospodăriilor fără copii $(32,7 \%)$, comparativ cu cea înregistrată în cazul gospodăriilor care au copii sub 18 ani în întreţinere (10,0\%) (Andrei, coord., 2018). 
Tabel 10. Nivelul și structura cheltuielilor totale, ale gospodăriilor de pensionari comparativ cu alte categorii de gospodării, în anii 2015, 2016

\begin{tabular}{|c|c|c|c|c|c|c|c|}
\hline & \multirow[b]{2}{*}{ Anii } & \multirow[b]{2}{*}{$\begin{array}{c}\text { Total } \\
\text { gospodării }\end{array}$} & \multicolumn{5}{|c|}{ Din care: } \\
\hline & & & Salariați & $\begin{array}{l}\text { Lucrători } \\
\text { pe cont } \\
\text { propriu în } \\
\text { activități } \\
\text { neagricole }\end{array}$ & Agricultori & Șomeri & Pensionari \\
\hline \multicolumn{8}{|l|}{$\begin{array}{l}\text { Cheltuieli } \\
\text { totale - lei }\end{array}$} \\
\hline $\begin{array}{l}\text {-medii } \\
\text { lunare / } \\
\text { gospodărie }\end{array}$ & $\begin{array}{l}2015 \\
2016\end{array}$ & $\begin{array}{l}2.351,5 \\
2.524,0\end{array}$ & $\begin{array}{l}3.182,2 \\
3.440,6\end{array}$ & $\begin{array}{l}1.853,8 \\
2.072,6\end{array}$ & $\begin{array}{l}2.020,6 \\
1.960,4\end{array}$ & $\begin{array}{l}1.526,2 \\
1.792,2\end{array}$ & $\begin{array}{l}1.755,0 \\
1.830,2\end{array}$ \\
\hline $\begin{array}{l}\text {-medii } \\
\text { lunare/ } \\
\text { persoană }\end{array}$ & $\begin{array}{l}2015 \\
2016\end{array}$ & $\begin{array}{l}884,6 \\
953,4\end{array}$ & $\begin{array}{l}1.092,3 \\
1.197,8\end{array}$ & $\begin{array}{l}554,7 \\
591,6\end{array}$ & $\begin{array}{l}600,8 \\
574,9\end{array}$ & $\begin{array}{l}471,7 \\
546,5\end{array}$ & $\begin{array}{l}809,3 \\
849,9\end{array}$ \\
\hline $\begin{array}{l}\text { Pondere în } \\
\text { veniturile } \\
\text { totale, \% }\end{array}$ & $\begin{array}{l}2015 \\
2016\end{array}$ & $\begin{array}{l}87,5 \\
85,7\end{array}$ & $\begin{array}{l}87,0 \\
84,9\end{array}$ & $\begin{array}{l}90,0 \\
91,1\end{array}$ & $\begin{array}{l}92,6 \\
90,9\end{array}$ & $\begin{array}{l}99,0 \\
93,6\end{array}$ & $\begin{array}{l}86,0 \\
85,1\end{array}$ \\
\hline \multicolumn{8}{|l|}{$\begin{array}{l}\text { \% în total } \\
\text { gospodării }\end{array}$} \\
\hline $\begin{array}{l}\text { - medii } \\
\text { lunare/ } \\
\text { gospodărie }\end{array}$ & $\begin{array}{l}2015 \\
2016\end{array}$ & $\begin{array}{l}100,0 \\
100,0\end{array}$ & $\begin{array}{l}135,3 \\
136,3\end{array}$ & $\begin{array}{l}78,8 \\
82,1\end{array}$ & $\begin{array}{l}85,9 \\
77,7\end{array}$ & $\begin{array}{l}64,9 \\
71,0\end{array}$ & $\begin{array}{l}74,6 \\
72,5\end{array}$ \\
\hline $\begin{array}{l}\text { - medii } \\
\text { lunare/ } \\
\text { persoană }\end{array}$ & $\begin{array}{l}2015 \\
2016\end{array}$ & $\begin{array}{l}100,0 \\
100,0\end{array}$ & $\begin{array}{l}123,5 \\
125,6\end{array}$ & $\begin{array}{l}62,7 \\
62,1\end{array}$ & $\begin{array}{l}67,9 \\
60,3\end{array}$ & $\begin{array}{l}53,3 \\
57,3\end{array}$ & $\begin{array}{l}91,5 \\
89,2\end{array}$ \\
\hline
\end{tabular}

Sursa: Pisică, Silvia, coord. ed., Coordonate ale nivelului de trai în România. Veniturile şi cheltuielile gospodăriilor populaţiei, în Anul 2016, INS, 2017

În anul 2016, cheltuielile totale ale gospodăriilor au fost, în medie, de 2.524,0 lei lunar pe gospodărie şi de 953,4 lei pe persoană. Acestea au reprezentat $85,7 \%$ din veniturile totale (în scădere cu 1,8 puncte procentuale faţă de anul 2015). Dintre categoriile de gospodării analizate cel mai înalt nivel al cheltuielilor totale, medii pe o persoană (1.197,8 lei lunar), a fost realizat de gospodăriile de salariaţi, care au dispus de veniturile cele mai mari, iar cel mai scăzut de gospodăriile de şomeri (546,5 lei). Niveluri mult mai scăzute, sub media pe ansamblul gospodăriilor au înregistrat gospodăriile de lucrători pe cont propriu în activităţi neagricole, agricultorii şi pensionarii, aceștia din urmă realizând doar $74,6 \%$ din media consumului gospodăriilor în anul 2015 și 72,5\% în anul 2016.

Sărăcia și excluziunea socială. În prezent, aproape fiecare a patra persoană din UE se află încă în risc de sărăcie sau excluziune socială. Sărăcia monetară, cea mai răspândită formă de sărăcie din UE.28, afecta 17,3\% din populația UE în 
2016. Ponderea medie a gospodăriilor cu o intensitate scăzută a muncii a rămas constantă, iar deprivarea materială severă a suportat cea mai consistentă scădere. Desigur, acești indicatori tind să se suprapună în cazul a numeroase persoane, acestea putând fi afectate de două sau chiar de toate cele trei tipuri de sărăcie.

Ponderea populației afectate de riscul sărăciei și excluziunii sociale în rândurile persoanelor vârstnice este însă mult mai ridicată $-34 \%$.

Tabel 11. Rata sărăciei şi excluziunii sociale în România în anul 2016 pentru diverse categorii de populație (\%)

\begin{tabular}{|c|c|c|c|c|c|c|c|c|}
\hline \multirow{2}{*}{$\begin{array}{c}\text { Total } \\
\text { populație }\end{array}$} & \multicolumn{2}{|c|}{ Gen } & \multicolumn{2}{c|}{ Vârstă } & \multicolumn{2}{c|}{ Structura familiei } & \multicolumn{2}{c|}{ Status ocupațional } \\
\cline { 2 - 9 } & F. & B. & $\begin{array}{c}\text { Sub 18 } \\
\text { ani }\end{array}$ & $65+$ ani & $\begin{array}{c}\text { Fără } \\
\text { copii }\end{array}$ & Cu copii & Angajați & Șomeri \\
\hline 38,8 & 39,8 & 37,8 & 49,2 & 34,0 & 34,2 & 42,5 & 29,2 & 73,5 \\
\hline
\end{tabular}

Sursa: EC, 2016, At risk of poverty or social exclusion in Romania, https://ec.europa. eu/eurostat/news/themes-in-the-spotlight/poverty-day-2017

Din tabelul nr.12 rezultă că, și după 30 de ani de la trecerea la economia de piață, largi categorii de populație din România, între care o bună parte din populația în vârstă de $65+$ ani, dispune de un standard de viață mai scăzut decât media populației, riscul de sărăcie şi excluziune socială afectând peste o treime din populaţie. Este adevărat, în cazul persoanelor vârstnice, acest risc este mai scăzut comparativ cu populaţia totală şi semnificativ mai scăzut faţă de cel al copiilor și tinerilor. Totuşi, trebuie să nu uităm că marea majoritate a persoanelor de $65+$ ani care trăiesc în sărăcie dispun de o situaţie economică nefavorabilă în condițiile în care acestea se află la capătul unei vieți de muncă susținută.

La nivelul UE.28, riscul de sărăcie și excluziune socială în gospodării cu cel puțin o persoană de $\mathbf{6 5}+$ ani, în anul $\mathbf{2 0 1 6}$, era de $15,3 \%$, adică ceva mai mic decât la nivelul populației europene totale (17,3\%) (tabel 12). În cazul României însă, acest indicator avea o valoare de 27,7\% - aproape de dublul mediei UE.28. 
Tabel 12. Riscul de sărăcie și excluziune socială în gospodării cu cel puțin o persoană de 65+ ani, $2016(\%)$

\begin{tabular}{|c|c|c|c|}
\hline Țara & $\begin{array}{c}\text { Gospodării cu cel puțin o } \\
\text { persoană de 65+ ani }\end{array}$ & Țara & $\begin{array}{c}\text { Gospodării cu cel puțin } \\
\text { o persoană de 65+ ani }\end{array}$ \\
\hline UE-28 & 15,3 & & 24,6 \\
\hline Belgia & 16,2 & Lituania & 7,6 \\
\hline Bulgaria & 37,9 & Luxemburg & 16,9 \\
\hline R. Cehă & 6,0 & Ungaria & 30,2 \\
\hline Danemarca & 5,1 & Malta & 10,5 \\
\hline Germania & 13,5 & Olanda & 11,7 \\
\hline Estonia & 16,9 & Austria & 14,9 \\
\hline Irlanda & 15,1 & Polonia & 22,3 \\
\hline Grecia & 22,4 & Portugalia & 27,7 \\
\hline Spania & 19,7 & România & 13,9 \\
\hline Franța & 8,4 & Slovenia & 12,9 \\
\hline Croația & 31,8 & Slovacia & 5,6 \\
\hline Italia & 18,5 & Finlanda & 6,6 \\
\hline Cipru & 24,4 & Suedia & 16,0 \\
\hline Letonia & 31,1 & M. Britanie & \\
\hline
\end{tabular}

Sursa: Di Meglio, E. et al., ed., Living conditions in Europe, 2018

Tabel 13. Sărăcia monetară și deprivarea materială severă, 2015 (\%)

\begin{tabular}{|c|c|c|c|c|}
\hline & \multicolumn{2}{|c|}{$\begin{array}{c}\text { Populație în risc de sărăcie } \\
\text { monetară }\end{array}$} & \multicolumn{2}{c|}{ Populație sever deprivată material } \\
\hline Vârsta & sub 65 de ani & $65+$ & sub 65 de ani & $65+$ \\
\hline România & 26,7 & 19,4 & 23 & 21,5 \\
\hline Bulgaria & 19,6 & 31,7 & 32,5 & 40,9 \\
\hline UE-28 & 18,1 & 14,1 & 8,7 & 5,6 \\
\hline
\end{tabular}

Sursa: Eurostat, 2015

Deşi riscul de sărăcie monetară în cazul populaţiei de 65+ ani este inferior celui al altor categorii de populație, totuși, nivelul mediu al veniturilor vârstnicilor îi situează pe majoritatea acestora, într-o zonă de precaritate economică, adică puţin deasupra pragului sărăciei, fără ca acest lucru să garanteze satisfacerea nevoilor de bază. 
Tabel 14. Rata deprivării materiale severe pe tipuri de gospodării în UE, 2016 (\%)

\begin{tabular}{|c|c|c|c|c|c|c|c|c|c|}
\hline \multirow[b]{2}{*}{ Țara } & \multicolumn{4}{|c|}{ Gospodării fără copii } & \multicolumn{5}{|c|}{ Gospodării cu copii } \\
\hline & $\begin{array}{l}\overline{\widetilde{\pi}} \\
\stackrel{0}{\circ}\end{array}$ & 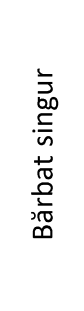 & 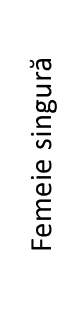 & 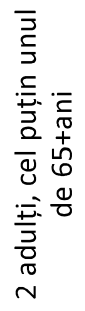 & $\begin{array}{l}\overline{\widetilde{\pi}} \\
\stackrel{\circ}{\circ}\end{array}$ & 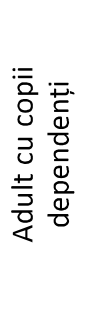 & 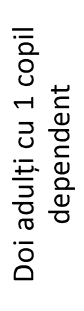 & 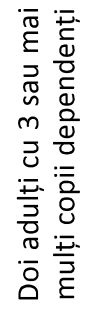 & 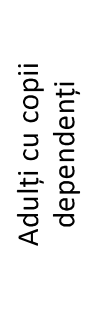 \\
\hline UE-28 & 7,0 & 10,9 & 10,0 & 4,3 & 8,0 & 15,7 & 5,2 & 9,7 & 77,2 \\
\hline Belgia & 4,7 & 10,6 & 8,0 & 1,2 & 6,3 & 14,9 & 3,1 & 7,9 & 5,2 \\
\hline Bulgaria & 31,9 & 37,5 & 54,7 & 32,4 & 32,1 & 56,2 & 22,1 & 85,5 & 30,6 \\
\hline R. Cehă & 4,3 & 7,8 & 7,5 & 2,2 & 5,3 & 17,0 & 4,6 & 8,4 & 4,3 \\
\hline Estonia & 5,9 & 11,9 & 7,9 & 3,3 & 3,5 & 13,3 & 3,1 & 5,2 & 2,6 \\
\hline Grecia & 19,1 & 22,9 & 22,4 & 12,8 & 26,1 & 36,2 & 18,6 & 34,3 & 25,7 \\
\hline Croația & 14,5 & 24,5 & 19,6 & 13,6 & 10,7 & 23,6 & 7,9 & 16,8 & 10,3 \\
\hline Letonia & 14,2 & 19,6 & 22,3 & 13,6 & 11,5 & 21,6 & 9,6 & 13,5 & 10,3 \\
\hline Lituania & 15,9 & 22,1 & 21,8 & 13,8 & 11,2 & 24,9 & 6,2 & 9,2 & 9,2 \\
\hline Ungaria & 14,2 & 24,5 & 15,9 & 9,4 & 18,4 & 42,3 & 14,2 & 22,9 & 15,9 \\
\hline Polonia & 7,7 & 18,1 & 11,7 & 5,7 & 5,2 & 21,6 & 3,1 & 7,5 & 4,7 \\
\hline România & 21,5 & 28,6 & 30,5 & 19,0 & 25,6 & 36,6 & 14,4 & 47,3 & 25,2 \\
\hline Slovacia & 8,3 & 17,8 & 11,6 & 9,3 & 8,1 & 24,5 & 3,2 & 14,9 & 7,5 \\
\hline
\end{tabular}

Sursa: Di Meglio, E. et al., ed., Living conditions in Europe, 2018

Mulți alți indicatori relevă această situație. De exemplu, extrem de relevantă este situația dificultăților întâmpinate de diferite categorii de gospodării, de a face față unor cheltuieli financiare neașteptate (tabel 15). Cuplurile de pensionari sunt cuprinse la categoria de gospodării de doi adulți din care cel puțin unul de 65+ ani - unde 49,8\% dintre gospodării declară neputința de a face față cheltuielilor neașteptate (comparativ cu $25,7 \%$ din gospodăriile similare din UE.28). 
Tabel 15. Neputința de a face față unor cheltuieli financiare neașteptate de diferite categorii de gospodării, în anul 2016 (\%)

\begin{tabular}{|c|c|c|c|c|c|c|c|c|}
\hline \multirow[b]{2}{*}{ Țara } & \multicolumn{4}{|c|}{ Gospodării fără copii } & \multicolumn{4}{|c|}{ Gospodării cu copii } \\
\hline & $\begin{array}{l}\bar{\pi} \\
\stackrel{\sqrt{0}}{0}\end{array}$ & 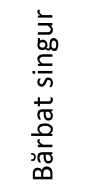 & 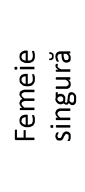 & 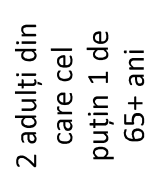 & $\begin{array}{l}\bar{\pi} \\
\stackrel{\pi}{0}\end{array}$ & 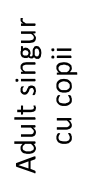 & 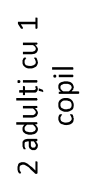 & 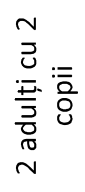 \\
\hline UE-28 & 33,6 & 39,7 & 46,5 & 25,7 & 39,3 & 65,2 & 32,6 & 31,6 \\
\hline Bulgaria & 58,0 & 70,3 & 86,6 & 68,8 & 50,6 & 77,1 & 46,7 & 45,4 \\
\hline R. Cehă & 30,4 & 38,6 & 50,2 & 23,6 & 33,7 & 67,7 & 29,4 & 27,9 \\
\hline Estonia & 33,0 & 42,0 & 45,3 & 28,2 & 30,2 & 55,2 & 29,4 & 25,1 \\
\hline Irlanda & 41,6 & 48,5 & 49,5 & 31,5 & 55,1 & 87,6 & 50,4 & 47,7 \\
\hline Grecia & 54,1 & 51,7 & 65,1 & 53,3 & 53,0 & 63,2 & 45,5 & 48,6 \\
\hline Croația & 60,6 & 67,1 & 75,6 & 58,6 & 55,3 & 79,4 & 50,5 & 51,1 \\
\hline Italia & 41,0 & 43,3 & 52,9 & 39,6 & 39,4 & 45,7 & 35,1 & 35,1 \\
\hline Cipru & 56,7 & 56,1 & 65,8 & 51,6 & 56,5 & 74,5 & 53,5 & 46,6 \\
\hline Letonia & 61,3 & 65,2 & 78,0 & 63,0 & 58,7 & 77,0 & 53,4 & 51,9 \\
\hline Lituania & 53,7 & 63,0 & 70,1 & 54,5 & 52,6 & 52,6 & 66,1 & 44,9 \\
\hline Ungaria & 45,5 & 52,3 & 54,1 & 36,0 & 56,4 & 84,4 & 47,0 & 43,7 \\
\hline Polonia & 40,0 & 48,2 & 60,5 & 37,4 & 36,2 & 67,5 & 30,6 & 31,9 \\
\hline Portugalia & 37,3 & 40,8 & 50,9 & 35,4 & 39,2 & 61,4 & 33,9 & 30,6 \\
\hline România & 53,4 & 60,6 & 72,3 & 49,8 & 55,4 & 74,7 & 45,0 & 52,0 \\
\hline Slovenia & 44,6 & 47,2 & 63,1 & 38,5 & 39,2 & 60,4 & 41,1 & 36,5 \\
\hline Slovacia & 36,0 & 50,3 & 50,2 & 38,6 & 39,4 & 62,5 & 30,0 & 34,2 \\
\hline
\end{tabular}

Sursa: Di Meglio, E. et al., (ed.), Living conditions in Europe, 2018

Persoanele vârstnice sunt cuprinse și în categoriile bărbat singur şi femeie singură, categorii care înregistrează în România, decalaje mari, comparativ cu gospodăriile similare din UE (Zamfir, E. și Zamfir, C., 2000). 


\section{Politici sociale și prognoză a cheltuielilor bugetare alocate până în anul 2070 în România}

În prezent, politicile de protecţie socială și cele de asistență socială a persoanelor vârstnice din România vizează trei dimensiuni principale: protejarea venitului; îngrijirea medicală; asistarea în vederea integrării sociale. Aceste politici se aplică prin intermediul protecției sociale cu principala sa platformă financiară reprezentată de sistemul public de pensii, prin sistemul de asistență socială și prin sistemul public de sănătate. Din principalii indicatori ai sistemului național de protecție socială reiese că în prezent, așa cum s-a întâmplat și pe parcursul anilor '90, sistemul național de protecție socială realizează cel mai scăzut randament social din UE.28 (ridică, prin distribuirea beneficiilor sociale, cea mai scăzută pondere a populației sărace, deasupra pragului de sărăcie) (Zamfir, E., 2000; Zamfir, E., 2009).

Viața în instituțiile de asistență socială din România. O parte a populației vârstnice trăiește în instituții de asistență socială (sau așteaptă să fie integrată în asemenea instituții) (Stănescu și Arpinte, 2015). În România, persoanele vârstnice singure sau ale căror familii nu pot să asigure, parțial sau integral, îngrijirea și întreținerea lor, pot apela la serviciile de asistență socială (tabel 15), fără a avea însă garanția unui răspuns favorabil, din cauza ofertei sociale foarte scăzute în raport cu cererea socială (Zamfir și Magino, 2013). Beneficiile și serviciile de asistență socială adresate persoanelor vârstnice sunt reglementate de Legea nr.17/2000, de Legea nr. 292/2011 și alte legi speciale (legislația pentru persoanele cu handicap, veteranii de razboi etc.). Acestea se adresează persoanelor vârstnice în situații de vulnerabilitate, respectiv:

a) care nu dispun de venituri proprii ori veniturile lor sau ale susținătorilor legali nu sunt suficiente pentru asigurarea unui trai decent;

b) care nu-şi pot desfăşura singure activităţile strict necesare ale vieții zilnice, nu se pot gospodări singure și necesită ajutor, asistență şi îngrijire;

c) nu dispun de o locuință și nici de posibilitatea de a-și asigura condițiile de locuit pe baza resurselor proprii;

d) se află în alte situații de urgență sau de necesitate, prevăzute de lege. 
Tabel 16. Cămine adresate persoanelor vârstnice din România - capacitatea acestora, număr de beneficiari și numărul de cereri în așteptare, în intervalul 2010-2016

\begin{tabular}{|c|c|c|c|c|c|c|}
\hline Anul & \multicolumn{2}{|c|}{2010} & \multicolumn{2}{|c|}{2014} & \multicolumn{2}{|c|}{2016} \\
\hline Categorii & Public & Privat & Public & Privat & Public & Privat \\
\hline Număr de cămine & 88 & 63 & 105 & 141 & 123 & 246 \\
\hline Capacitate (număr de locuri) & 6.438 & 2.160 & 7.019 & 5.600 & 7.630 & 9.659 \\
\hline $\begin{array}{l}\text { Număr mediu lunar de } \\
\text { beneficiari }\end{array}$ & 5.587 & 1.957 & 5.892 & 4.657 & 6.488 & 8.102 \\
\hline Număr de cereri în așteptare & \multicolumn{2}{|c|}{2.834} & \multicolumn{2}{|c|}{2.379} & \multicolumn{2}{|c|}{1.017} \\
\hline
\end{tabular}

Sursa: Consiliul Național al Persoanelor Vârstnice, 2018, Asistența socială a persoanelor vârstnice

Persoanele ce dispun de pensie sub un anumit cuantum lunar pot beneficia de asistență socială, în următoarele situații:

a) beneficii de asistență socială pentru prevenirea și combaterea sărăciei și a riscului de excluziune socială;

b) indemnizații de îngrijire, acordate în condițiile legii;

c) alocații pentru asigurarea calităţii serviciilor sociale, destinate acoperirii costurilor hranei în cantine sociale, în centrele rezidențiale de îngrijire, sau pentru susținerea unor suplimente nutriționale;

d) facilități privind transportul urban și interurban, telefon, radio-tv, achiziția de produse alimentare, bilete de tratament balnear sau pentru recreere, precum și a altor servicii.

În luna februarie 2018, în România existau doar 39 de unități publice de îngrijire la domiciliu și 107 cămine pentru persoane vârstnice. Principala sursă de venituri a persoanelor în vârstă de 65 de ani și peste sunt prestațiile sociale. 
Tabel 17. Venitul median net echivalent (PPS) înainte şi după transferurile sociale, pe categorii de gospodării, în țările UE.28, în anul 2016

\begin{tabular}{|c|c|c|c|c|c|c|}
\hline \multirow[b]{2}{*}{ Țara } & \multicolumn{3}{|c|}{ Înainte de transferurile sociale } & \multicolumn{3}{|c|}{ După transferurile sociale } \\
\hline & 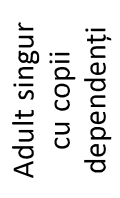 & 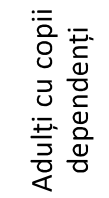 & 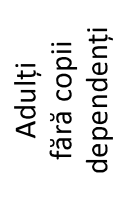 & 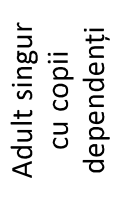 & 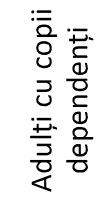 & 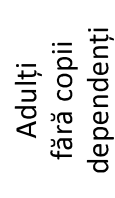 \\
\hline UE-28 & 8487 & 10141 & 13815 & 13165 & 18492 & 15887 \\
\hline Belgia & 9248 & 9742 & 19607 & 13594 & 22264 & 22444 \\
\hline Bulgaria & 3589 & 4747 & 5239 & 4249 & 7910 & 6513 \\
\hline R.Cehă & 7471 & 8754 & 11617 & 8513 & 13507 & 12954 \\
\hline Danemarca & 14585 & 12222 & 22051 & 16960 & 21824 & 23521 \\
\hline Germania & 10921 & 13867 & 18746 & 15021 & 23197 & 21915 \\
\hline Estonia & 7745 & 8959 & 10839 & 9307 & 12486 & 13025 \\
\hline Irlanda & 2757 & 11082 & 14830 & 12006 & 20259 & 18036 \\
\hline Grecia & 5584 & 2819 & 6607 & 6861 & 9592 & 8070 \\
\hline Spania & 8891 & 7975 & 12201 & 10487 & 16720 & 14297 \\
\hline Franța & 10076 & 10160 & 17972 & 14197 & 23041 & 20578 \\
\hline Croatia & 5085 & 5171 & 7174 & 7124 & 9505 & 8776 \\
\hline Italia & 10700 & 7801 & 12593 & 12269 & 16979 & 14561 \\
\hline Ciprus & 8840 & 9054 & 14246 & 12231 & 15985 & 16605 \\
\hline Letonia & 5035 & 6553 & 8474 & 6813 & 9658 & 10036 \\
\hline Lituania & 5392 & 7254 & 8289 & 6564 & 11001 & 9943 \\
\hline Luxemburg & 12636 & 17692 & 22631 & 18403 & 33613 & 27588 \\
\hline Ungaria & 3885 & 5470 & 6057 & 5827 & 9586 & 8020 \\
\hline Malta & 7373 & 12813 & 15789 & 11660 & 18361 & 17177 \\
\hline Olanda & 10235 & 14156 & 20485 & 15640 & 23079 & 21871 \\
\hline Austria & 11372 & 15260 & 17047 & 16418 & 26180 & 20991 \\
\hline Polonia & 6447 & 6714 & 8586 & 8054 & 12021 & 10396 \\
\hline Portugalia & 6947 & 4264 & 9278 & 8063 & 11614 & 10536 \\
\hline România & 2508 & 3097 & 3254 & 3169 & 5841 & 4287 \\
\hline Slovenia & 10282 & 8010 & 13849 & 12460 & 16513 & 16034 \\
\hline Slovacia & 6689 & 8212 & 8188 & 7571 & 12110 & 9786 \\
\hline Finlanda & 10663 & 12166 & 17890 & 15282 & 22431 & 20824 \\
\hline
\end{tabular}




\begin{tabular}{|l|c|c|c|c|c|c|}
\hline Suedia & 11714 & 13223 & 17970 & 14879 & 24313 & 21705 \\
\hline M.Britanie & 3635 & 14238 & 15472 & 11891 & 20997 & 17051 \\
\hline
\end{tabular}

Sursa: Di Meglio, E. et al., ed., Living conditions in Europe, 2018 edition

Ca urmare, Ministerul Muncii ar trebui să transforme sistemul de asistenţă socială asigurând trecerea de la un stil de lucru bazat pe beneficii, la unul axat pe oferta de servicii persoanelor aflate în situații de necesitate. În acest sens, sunt deja în pregătire două proiecte de Hotărâre de Guvern, unul privind dezvoltarea serviciilor comunitare la domiciliu pentru persoanele vârstnice dependente și celălalt privind creșterea capacității serviciilor publice de asistență socială din unele unităţi administrativ-teritoriale (Golea, 2018).

În anul 2016, gospodăriile românești au beneficiat de prestaţii sociale al căror nivel mediu lunar a fost de 664,1 lei (Andrei, coord., 2018), contribuind la formarea veniturilor băneşti în proporţie de $25,2 \%$. Cea mai mare parte a acestor venituri a constituit-o pensiile $(85,4 \%)$. Pensiile de asigurări sociale de stat pentru limită de vârstă (inclusiv pensiile anticipate şi anticipate parţial), pentru pierderea capacităţii de muncă şi de urmaş au reprezentat $79,3 \%$, pensiile de asigurări sociale pentru agricultori - 6,1\%, pensiile IOVR fiind nesemnificative (sub 0,1\%) (Andrei, coord., 2018).

Rata riscului de sărăcie după transferurile sociale, la nivelul UE.28, a scăzut, în anul 2016, cu 8,6 puncte procentuale. Sărăcia monetară medie după efectuarea transferurilor sociale de $17,3 \%$ (circa $86,9 \%$ milioane de persoane) din țările UE.28 a fost ceva mai scăzută decât cea aferentă economiilor avansate din afara UE (OCDE - 20-25\%). În anul 2016, 7,8\% din populația UE.28 era încă expusă riscului sărăciei, deși lucra cu normă întreagă (Di Meglio et al., ed., 2018).

În anul 2016, peste 37 de milioane de persoane sau aproape o treime $(31,7 \%)$ din totalul celor expuse riscului sărăciei sau excluziunii sociale, în UE.28, au fost afectate de mai mult de o dimensiune a sărăciei. Circa 8,4 milioane de persoane sau 1 din 14 persoane expuse riscului sărăciei sau excluziunii sociale $(7,1 \%)$ au fost afectate de toate cele trei categorii de riscuri.

Din tabelul nr. 18, reiese că persoanele de 65+ ani din România, indiferent de categoriile de gospodării în care trăiau, beneficiau de un venit median net echivalent mult mai mic decât oricare dintre persoanele similare aflate în gospodăriile aferente celorlalte state din UE.28 (chiar și decât cel aferent Bulgariei). Acest indicator este relevant, deopotrivă, pentru ilustrarea randamentului extrem de scăzut al sistemului de protecție socială din România, comparativ cu sistemele europene, dar și pentru ilustrarea nivelului relativ scăzut al venitului mediu al populației din România.

Prognoză privind îmbătrânirea demografică și proiecția cheltuielilor bugetare corelate. Prognoza Comisiei Europene pentru intervalul 2016-2070 prevede un fenomen al îmbătrânirii demografice mai accentuat pentru categoria 
65+ din România, structurat în jurul mediei de 11,6\% din populaţia totală, decât pentru nivelul mediu European, îndeosebi după anul 2040 (tabel 18).

Tabel 18. Populație de 65+ (\% din populația totală) România 2016-2070

\begin{tabular}{|c|c|c|c|c|c|c|c|c|c|c|c|c|c|}
\hline & 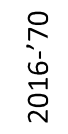 & 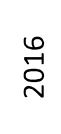 & 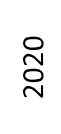 & $\stackrel{\sim}{\sim}$ & 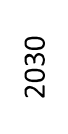 & $\stackrel{\sim}{\stackrel{N}{N}}$ & 定 & $\stackrel{\text { : }}{\stackrel{N}{N}}$ & 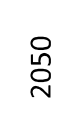 & $\stackrel{\text { 兌 }}{\text { N }}$ & ஜ্ণ & 怘 & $\stackrel{\circ}{\stackrel{2}{N}}$ \\
\hline România & 11,6 & 17,6 & 19,4 & 21,4 & 21,9 & 24,7 & 26,8 & 29,0 & 29,9 & 31,2 & 30,7 & 29,9 & 29,2 \\
\hline UE. 28 & 9,5 & 19,3 & 20,5 & 22,2 & 24,1 & 25,9 & 27,1 & 28,0 & 28,5 & 28,9 & 29,0 & 28,9 & 28,8 \\
\hline
\end{tabular}

Sursa: European Commission, The 2018 Aging Report Economic and Budgetary Projections for the 28 EU Member States (2016-2070), Institutional Paper 079, May 2018

Lucrul acesta este adevărat și în ceea ce privește populația de $80+$, dar în jurul unei medii ceva mai mici, de $9,2 \%$ din populația totală.

Tabel 19. Populație de 80+ (\% din populaţia totală) România 2016-2070

\begin{tabular}{|c|c|c|c|c|c|c|c|c|c|c|c|c|c|}
\hline & $\begin{array}{l}\stackrel{0}{1} \\
\dot{0} \\
\stackrel{0}{1} \\
\end{array}$ & 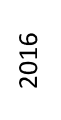 & ્ָరి & $\stackrel{\sim}{\tilde{N}}$ & 商 & $\stackrel{\text { }}{\stackrel{N}{N}}$ & 定 & 占 & 号 & $\stackrel{\text { 号 }}{\text { N }}$ & : & $\stackrel{\leftrightarrow}{\stackrel{\leftrightarrow}{~}}$ & 号 \\
\hline România & 9,2 & 4,3 & 4,8 & 5,0 & 5,9 & 7,3 & 8,4 & 8,2 & 9,9 & 11,3 & 12,6 & 12,9 & 13,5 \\
\hline UE. 28 & 7,1 & 5,4 & 5,9 & 6,4 & 7,3 & 8,2 & 9,2 & 10,3 & 11,2 & 11,8 & 12,1 & 12,3 & 12,5 \\
\hline
\end{tabular}

Sursa: European Commission, The 2018 Aging Report Economic and Budgetary Projections for the 28 EU Member States (2016-2070), Institutional Paper 079, May 2018

Din proiecția resurselor bugetare destinate finanțării diferitelor politici sociale adresate fenomenului îmbătrânirii populației, la nivelul mediei UE.28, în intervalul 2016-2040, se va acorda un plus de 0,8 puncte procentuale din PIBul mediu al UE (tabel 20) pentru sistemele de pensii. În România, cheltuielile de acest tip se vor ridica la 0,7 puncte procentuale din PIB și vor fi distribuite ca medie, pe intervalul 2016-2070. 
Tabel 20. Proiecții ale cheltuielilor bugetare corelate cu îmbătrânirea populației (20162070), pe capitole de cheltuieli, (în puncte procentuale din PIB)

\begin{tabular}{|c|c|c|c|c|c|c|c|c|c|c|c|c|}
\hline \multirow[b]{2}{*}{ An(ii) } & \multicolumn{3}{|c|}{ Pensii } & \multicolumn{3}{|c|}{ Sănătate } & \multicolumn{3}{|c|}{$\begin{array}{l}\text { Îngrijire pe } \\
\text { termen lung }\end{array}$} & \multicolumn{3}{|c|}{$\begin{array}{c}\text { Itemi corelați cu } \\
\text { îmbă-trânirea } \\
\text { populației }\end{array}$} \\
\hline & $\begin{array}{l}0 \\
\stackrel{1}{N}\end{array}$ & $\begin{array}{l}\text { O } \\
\stackrel{1}{1} \\
\dot{0} \\
\stackrel{1}{N}\end{array}$ & 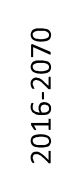 & $\begin{array}{l}0 \\
\text { - } \\
\text { N }\end{array}$ & 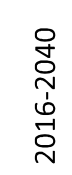 & 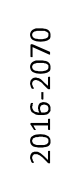 & $\begin{array}{l}0 \\
\stackrel{1}{N}\end{array}$ & $\begin{array}{l}\text { O } \\
\text { } \\
\text { bे } \\
o \dot{0}\end{array}$ & 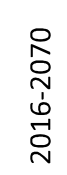 & $\begin{array}{l}0 \\
\stackrel{1}{N}\end{array}$ & 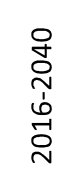 & 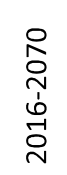 \\
\hline $\begin{array}{l}\text { Medie } \\
\text { UE.28 }\end{array}$ & 11,2 & $+0,8$ & $-0,2$ & 6,8 & $+0,6$ & $+0,9$ & 1,6 & $+0,6$ & $+1,2$ & 24,1 & $+2,0$ & $+1,8$ \\
\hline $\begin{array}{c}\text { România } \\
\text { (\%) }\end{array}$ & 8,0 & $-0,3$ & $+0,7$ & 4,3 & $+0,8$ & $+0,9$ & 0,3 & $+0,2$ & $+0,3$ & 15,0 & $+0,7$ & $+2,2$ \\
\hline
\end{tabular}

Sursa: European Commission, The 2018 Aging Report Economic and Budgetary Projections for the 28 EU Member States (2016-2070), Institutional Paper 079, May 2018

La capitolul medical, la nivelul mediei țărilor UE, în intervalul 2016-2070, se va aloca o medie de 0,9 puncte procentuale din PIB-ul mediu european, pondere valabilă și pentru PIB-ul mediu din România (tabel 20).

Pentru îngrijirea pe termen lung prognoza europeană prevede o cheltuială de 1,2 puncte procentuale din PIB-ul mediu european, iar pentru România, doar 0,7 puncte procentuale din media PIB a României, în condițiile în care România înregistrează deja un serios deficit la acest capitol, iar prognoza demografică indică o accentuare a acestui tip de problemă socială, îndeosebi după anul 2040 (tabel 20).

Per ansamblu, itemii corelați cu îmbătrânirea populației se vor ridica la 2,2 puncte procentuale din PIB pentru România și la 1,8 puncte procentuale din media PIB-ului european, la nivelul UE.28, în intervalul 2016-2070 (tabel 21).

Tabel 21. Populație 80+ (\% din populația vârstnică) România în intervalul 2016-2070

\begin{tabular}{|c|c|c|c|c|c|c|c|c|c|c|c|c|c|}
\hline & $\begin{array}{l}\stackrel{P}{1} \\
\text { í } \\
o \\
0 \\
\text { N }\end{array}$ & $\begin{array}{l}\stackrel{0}{0} \\
\stackrel{\sim}{N}\end{array}$ & 苂 & $\stackrel{\sim}{\underset{N}{\sim}}$ & ஜ & 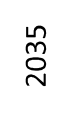 & 웜 & 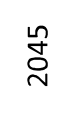 & 圆 & 㞫 & : & ஜூ & 옹 \\
\hline România & 21,8 & 24,4 & 24,9 & 23,3 & 26,8 & 29,7 & 31,2 & 28,4 & 33,2 & 36,1 & 41,2 & 43,1 & 46,2 \\
\hline UE.28 & 15,5 & 28,1 & 28,9 & 28,6 & 30,2 & 31,7 & 33,9 & 36,6 & 39,2 & 40,7 & 41,8 & 42,6 & 43,6 \\
\hline
\end{tabular}

Sursa: European Commission, The 2018 Aging Report Economic and Budgetary Projections for the 28 EU Member States (2016-2070), Institutional Paper 079, May 2018 
O problemă socială certă derivă în viitor din faptul că populația de $80+$ ani din România, ce reprezenta $24,4 \%$ din populația vârstnică în anul 2016, va crește lent dar continuu ca pondere atingând 41,2\% în anul 2060 şi 46,2\% în anul 2070. O asemenea evoluție demografică, pe lângă prevederea fondurilor absolut necesare pentru asigurarea unei asistențe sociale de nivel decent, presupune înființarea unor servicii de îngrijire la nivel comunitar sau/şi în sistem centralizat, care să răspundă într-un fel sau altul, cererii specifice de servicii ce se va contura în etapa respectivă.

\section{Concluzii}

1. Ca efect al îmbătrânirii populaţiei din România vor creşte solicitările adresate serviciilor medicale, serviciilor comunitare și instituțiilor de asistență socială. În anul 1999, îngrijirea sănătății a devenit unul dintre cele patru domenii ale protecţiei sociale. Consiliul european de la Lisabona (2000) a abordat pe larg posibilitatea de a oferi servicii de sănătate de calitate, iar Consiliul de la Götteborg (2001) a repus problema cadrului instituțional și comunitar pentru acordarea de îngrijiri persoanelor vârstnice. Sistemele de îngrijire și asistare a sănătății pe termen lung adresate persoanelor vârstnice vor trebui să gestioneze trei domenii esenţiale: 1 . asigurarea accesului solicitanților în stare de necesitate, indiferent de veniturile lor, la un nivel decent al calităţii îngrijirii, 2. asigurarea sustenabilității financiare a sistemelor de îngrijire, și 3. asigurarea unui raport calitate/preț just al serviciilor acordate contra cost.

2. Principalii factori ce condiționează calitatea vieții vârstnicilor din România decurg din dimensiunea economică a vieții sociale. Ca urmare, politicile sociale vizând condițiile de viață ale vârstnicilor din țara noastră trebuie să țină seama de realitățile social-economice existente și de evoluțiile previzibile ale acestora pe termen mediu și lung. Menţinerea unui grad ridicat de protecţie socială, implică revederea şi readaptarea din mers, continuă, a politicilor şi strategiilor adresate segmentului de persoane vârstnice, corelat cu trebuințele celorlalte segmente ale populației. Asta deoarece în comunitățile moderne în care, de-a lungul timpului, gospodăriile se structurează pe un număr tot mai redus de membri, pare a fi exclusă o revenire la condiţiile de viaţă ale unei epoci în care familia lărgită își putea asuma şi asigura mijloacele de existenţă şi îngrijirea persoanelor vârstnice. Ca urmare, reformele europene ale viitorului trebuie să ofere soluții ingenioase de constituire și transfer al resurselor necesare, cel puțin până spre anii 2050, către un segment relativ mare al populației (în jur de 30\%), fără a genera tensiuni economice sau sociale majore. Asta pentru a nu permite căderea în sărăcie a populaţiei vârstnice. Sub o formă sau alta, transferurile au existat şi vor exista totdeauna. Două concepte vor trebui avute permanent în vedere: solidaritatea intre generaţii - ce vizează finanţarea sistemului pe termen lung, şi echitatea între generaţii - ce crește în relevanță pentru toate generațiile. Decidenții politici vor trebui să ţină seama de aceste principii, pentru asigurarea unui echilibru cât mai 
satisfăcător între posibilităţile de finanţare şi satisfacerea imperativelor sociale generate de trebuinţele sociale și de asigurarea echității între generaţii.

3. Diferențele relativ mari existente între unele prognoze socio-economice formulate până în prezent de diverse instituții specializate, cu privire la perspectivele următoarelor două-trei decenii, situează viitorul populației de $65+$ ani, sub incidența incertitudinii. Totuși, o serie de trebuințe sociale, cum sunt cele ale vârstnicilor, al căror număr, cel mai probabil, va crește în deceniile viitoare sunt lesne de prevăzut. Ca urmare, crearea premiselor obiective pentru asigurarea unor condiții de viață minim decente persoanelor vârstnice ar trebui să preocupe mediul politic, de vreme ce toată lumea speră să mai trăiască cel puțin în jur de două decenii după vârsta pensionării.

\section{Notă}

Această lucrare a fost realizată prin Planul sectorial de cercetare - dezvoltare al Ministerului Muncii și Protecției Sociale pentru perioada 2018-2020, contract nr. 3676/28.09.2018, proiect cu titlul „Calitatea vieţii persoanelor vârstnice dependente în România”.

\section{Bibliografie}

Andrei, T. (coord.) (2018) Starea economică şi socială a României 2015 şi 2016. Date statistice. București: INS.

Camera de Comerț și Industrie a României (2018) Analiză privind evoluția economiei României în 2017. Disponibil la https://ccir.ro/2018/03/13/analiza-privind-evolutiaeconomiei-ro-2017/.

CECCARFM (2017) Ponderea agriculturii în PIB-ul României a scăzut de la 22,6\% (1993) la 3,9\% (2016). Economie. 7 martie. Disponibil la http://ceccarfm.ro/2017/03/ ponderea-agriculturii-in-pib-ul-romaniei-a-scazut-de-la-226-1993-la-39-2016/.

Comper, M. (2011) Care este secretul vieții de 100 de ani?, Descoperă.ro, 3 octombrie.

Consiliul Național al Persoanelor Vârstnice (2018) Asistența Socială a Persoanelor Vârstnice. Disponibil la https://www.cnpv.ro/pdf/analize2018/studiu-AsistentaSociala-MP.pdf.

Di Meglio, E. et al. (ed.) (2018) Living conditions in Europe. Luxembourg.

Divizia pentru Populaţie a Departamentului Afacerilor Socio-Economice din cadrul Naţiunilor Unite (2010) Estimări privind populaţia lumii, ediţia revizuită.

European Commission (2014) Population ageing in Europe, Facts, implications and policies.

European Commission (2016) Statistical Annex of European Economy, Spring 2016, Directorate General for Economic and Financial Affairs.

European Commission (2017) European Commission and its priorities, Romania, Economy. Disponibil la https://ec.europa.eu/info/business-economy-euro/ economic-performance-and-forecasts/economic-performance-country/romania/ economic-forecast-romania_en. 
European Commission (2018) The 2018 Ageing Report: Economic and Budgetary Projections for the EU Member States (2016-2070), Institutional Paper 079, Directorate-General for Economic and Financial Affairs. doi: 10.2765/615631.

European Commission (2018) A look at the lives of the elderly in the EU today, eurostat. Disponibil la https:/ec.europa.eu/eurostat/cache/infographs/elderly/index.html.

Eurostat (2018) A look at the lives of the elderly in the EU today. Disponibil la https:// ec.europa.eu/eurostat/cache/infographs/elderly/index.html.

Eurostat (2018) GDP per capita, consumption per capita and price level indices. https://ec.europa.eu/eurostat/statistics-explained/index.php/GDP_per_capita, consumption_per_capita_and_price_level_indices

Eurostat (2019) Healthy life years and life expectancy at age 65 by sex. Diponibil la https://ec.europa.eu/eurostat/tgm/refreshTableAction. do $?$ tab $=$ table\&plugin $=1 \&$ pcode $=$ tepsr_sp320\&language $=$ en.

Eurostat (2019) Life expectancy at birth by sex https://ec.europa.eu/eurostat/tgm/ refreshTableAction.do?tab=table\&plugin $=1 \&$ pcode $=$ sdg_03_10\&language $=$ en.

Focuseconomics (2018) Economic Forecasts from the World's Leading Economists. Disponibil la https://www.focus-economics.com/countries/romania.

Golea, S. (2018) Bătrânii vor fi îngrijiți la domiciliu de asistenți sociali. Beneficiari vor fi peste 300.000 de vârstnici dependenți. Libertatea, 8 mai. Disponibil la https://www.libertatea.ro/stiri/social/caminele-de-batrani-se-vor-muta-acasa-lavarstnici-2243819.

INS (2011) Comunicat de presă Nr.140/2011.

INS (2016) Nivel de trai, Comunicat de presă, Nr.85/6 aprilie.

INSSE (2018) Populaţia după domiciliu la 1 ianuarie 2018. Disponibil http://www. insse.ro/cms/ro/content/popula\%C5\%A3ia-dup\%C4\%83-domiciliu-la-1ianuarie-2018.

Meleniuc, S. (2018) Romania's economic growth in 2017 revised down to 6.9 pct; GDP revised up to EUR 187.8 billion, Romania GDP Growth Rate.

OECD și EU (2018) Health at a Glance: Europe 2018, State of Health in the EU Cycle. OECD Publishing, Paris. https://doi.org/10.1787/health_glance_eur-2018-en.

Redactia Alba24.ro (2016) INS: Trăim mai mult, dar speranța de viață sănătoasă este în scădere. La 1900, durata medie a vieții unui român era de numai 36 de ani. 15 decembrie. Disponibil la https://alba24.ro/ins-traim-mai-mult-dar-speranta-deviata-sanatoasa-este-in-scadere-la-1900-durata-medie-a-vietii-unui-roman-era-denumai-36-de-ani-538487.html.

Ro.Insider (2017) Purchasing power in Romania, a third of European average despite 12\% growth in 2016, 18 Jan, Ro Insider. Disponibil la https:/www.romania-insider.com/ purchasing-power-in-romania-a-third-of-european-average/.

Roșu, R. (2017) INS: România are 5,22 milioane de pensionari, pensia medie fiind de 1.022 lei pe lună. $Z F, 12$ septembrie. Disponibil la https://www.zf.ro/companii/ ins-romania-are-5-22-milioane-de-pensionari-pensia-medie-fiind-de-1-022-lei-peluna-16725415.

United Nations (2017) World Population Prospects: The 2017 Revision, World Population Ageing, 2017. Department of Economic and Social Affairs, Population Division, United Nations, New York. 
Vulea, P. (2018) România are a patra cea mai mică speranță de viață din UE, Radio România. Disponibil la http://www.radiooltenia.ro/romania-are-a-patra-cea-maimica-speranta-de-viata-din-ue/. Accesat în 25 noiembrie 2018.

Zamfir, E. (coord.) (2000) Strategii anti-sărăcie şi dezvoltare comunitară. București: Expert.

Zamfir, E. și Zamfir, C. (2000) Situaţia femeii în România, în tranziţie. Bucureşti: Expert.

Zamfir, E. (2009) Asistența socială în România. Teorie și acţiune socială. Craiova: Mitropoliei Olteniei.

Zamfir, E. și Magino, F. (ed.) (2013) The European Culture Of Human Rights. The Right to Hapyness. Newcastle: The Cambridge Scholars Publishing.

Zamfir, E., Stănescu, S. și Arpinte, D. (coord.) (2015) Asistența Socială în România după 25 de ani: răspuns la problemele tranziției. Cluj-Napoca: Școala Ardeleană, Eikon.

ZF (2016) România, pe locul 6 în UE la ponderea industriei în PIB. Disponibil la https://www.zf.ro/eveniment/ romania-pe-locul-6-in-ue-la-ponderea-industriei-inpib-16012618).

Wold Economic Forum (2016) The Global Competitiveness Report 2016-2017. Geneva.

World Health Organization (2016) World Health Statistics, 2016. Monitoring health for the SDGs.

https://stirileprotv.ro/stiri/social/fenomenul-de-imbatranire-demografica-se-accentueazain-romania-peste-30-de-ani-situatia-va-fi-mult-mai-rea.html. 